Vol. 52, no. 2 (2014), pp. 459-485, doi: 10.14421/ajis.2014.522.459-485

\title{
NEW TRENDS IN ISLAMIC POLITICAL PARTIES IN THE ARAB SPRING COUNTRIES
}

\author{
Ibnu Burdah \\ Sunan Kalijaga State Islamic University (UIN) Yogyakarta, Indonesia \\ email: ibnuburda@yahoo.com
}

\section{Abstract}

The recent developments of Islamic political parties in the Arab spring countries show new orientation and agendas, i.e. reconfirmation of their commitment to democratic values, strengthening civil society, and adopting human rights principles. In the same time, they indicate not to be interested in the old Islamic agendas relating to jihad for Islamic states (dawlah Islāmiyah) and "global Islamic government" under one centralized caliphate (al-khilāfah al-Islāmiyyah). It is the case of Justice and Development Party (Hizb al'Adālah wa'l-Tanmiyah) in Morocco, Freedom and Justice Party (Hizb al-Hurriyyah wa'l-'Adālah) in Egypt, and Awakening Party (Hizb al-Nahdiah) in Tunis. This paper seeks to explore and explain this new fact. Based on literary research and interviews with the leaders of the Justice and Development Party (Hizb al-'Adālah wa'l-Tanmiyah) in Morocco, the paper concludes that the new orientation and agendas of Islamic political parties in the Arab spring states are related to democratization in the world, strong waves of Arab spring in many Arab states, and the dynamics of the internal parties.

Perkembangan mutakhirpartai-partai politik Islam di sejumlah negara Arab "Musim Semi" menunjukkan adanya perubahan orientasi dan agenda baru, berupa penegasan kembali komitmen merek a terhadap nilai-nilai demokrasi, penguatan masyarakat sipil, dan adopsi prinsip-prinsip bak asasi manusia. Pada saat yang sama, merek a tampak kurang tertarik kepada agenda-agenda politik Islam lama seperti jihad bagi pendirian negara Islam dan pendirian pemerintahan Islam global di bawah satu khalifah yang tersentralisasi. Hal ini relevan terhadap kasus Partai Keadilan dan Pembangunan (Hizb 
Ibnu Burdah

al-'Adālah wa'l-Tanmiyah) di Maroko, Partai Kebebasan dan Keadilan (Hizb al-Hurriyyah wa'l-'Adālah) di Mesir, dan Partai Kebangkitan (Hizb al-Nahḍah) di Tunisia. Artikel ini berupaya mengeksplorasi dan menjelaskan fakta baru ini. Berdasarkan kajian pustaka dan wawancara dengan sejumlah petinggi Partai Keadilan dan Pembangunan di Maroko, penulis berkesimpulan bahwa orientasi baru ini terjadi akibat dari gelombang demokratisasi dunia, "angin kencang musim semi" Arab yang begitu kuat, dan dinamika internal partai.]

Keywords: Islamic political parties, ideological moderation, Arab springs, democratization

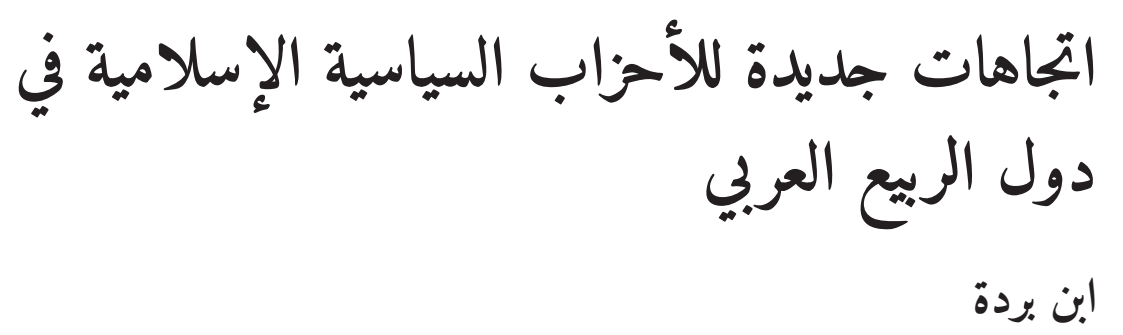

جامعة سونن كالجاكا الإسلامية الحكومية، يوكياكوتا، اندونيسيا

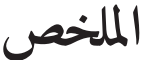

هنال وقائع جديدة في تطور الأحزاب الإسلامية في دول الربيع العربي

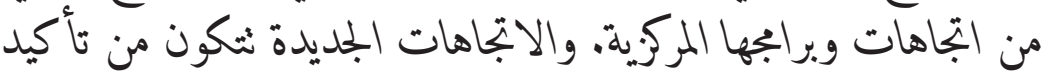

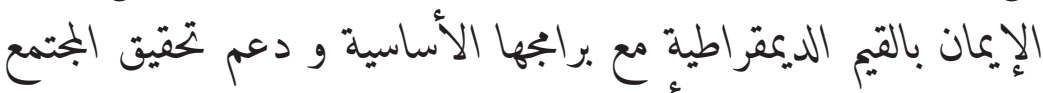

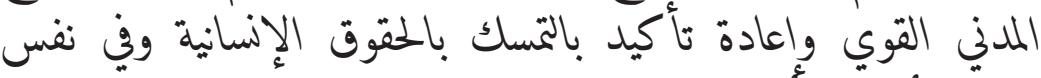

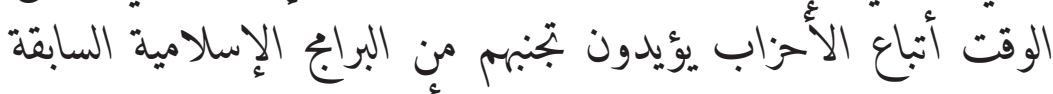

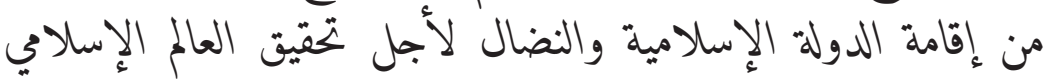

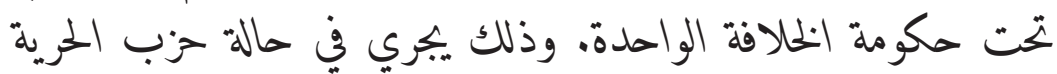

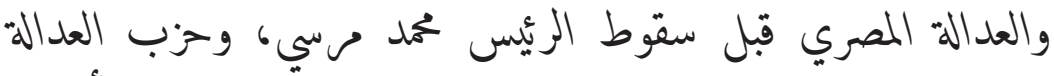

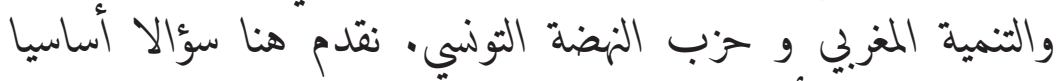

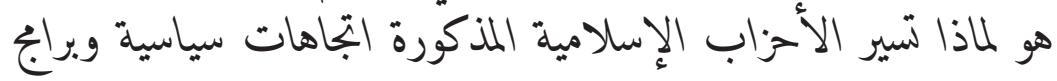


جديدة ؟ هذا البحث المكتبي والميداني يكشف علاقة الاتجاهات

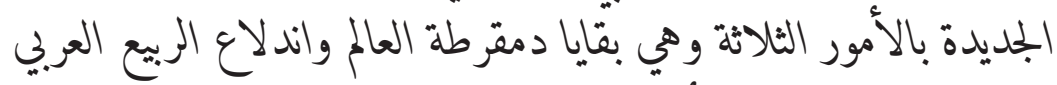
والتطورات الداخلية لأحزّاب الإسلامية.

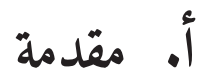

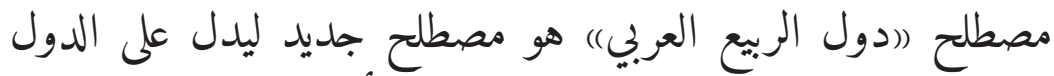

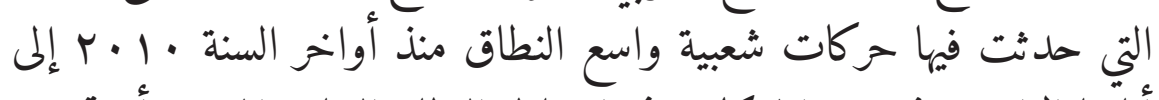

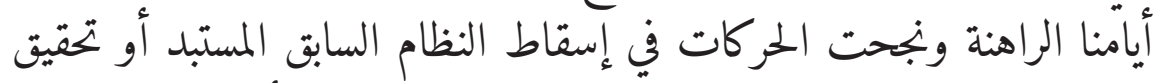

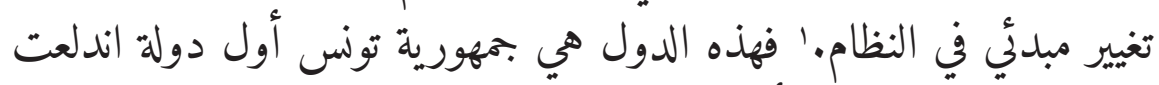

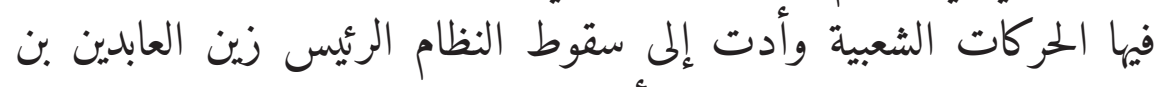

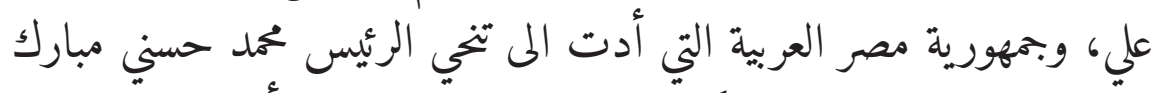

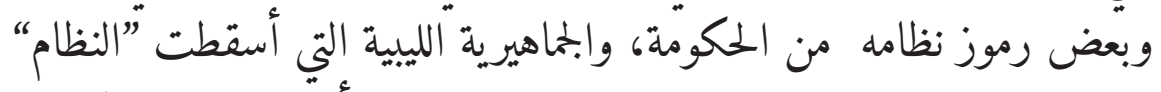

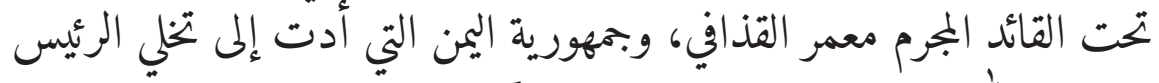

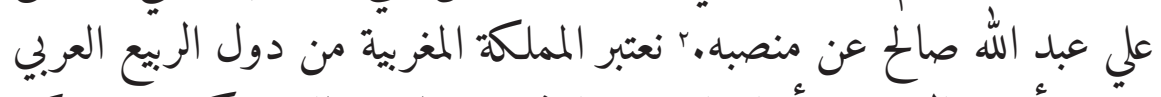

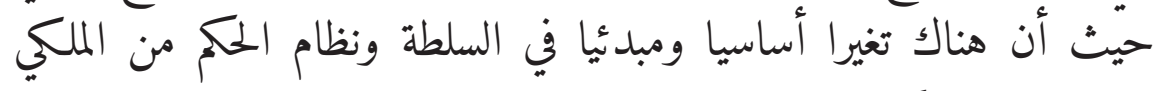

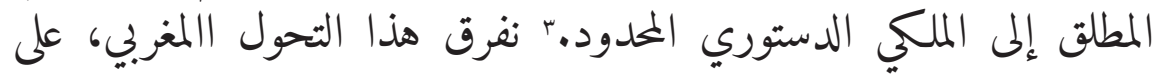

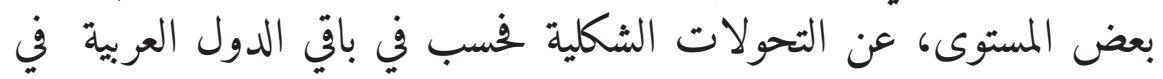
رد فعلها على مطالب الشعب.

' عبد الحي مودن، أسئلة حول انطلاق الربيع العربي (الرباط:

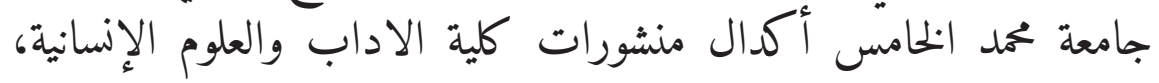

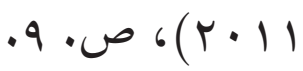
r باري، الطاهر عطاف، الربيع العربي والعجز الديمقراطي (الرباط: مطبعة

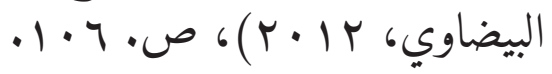

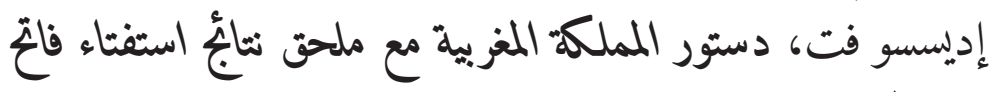

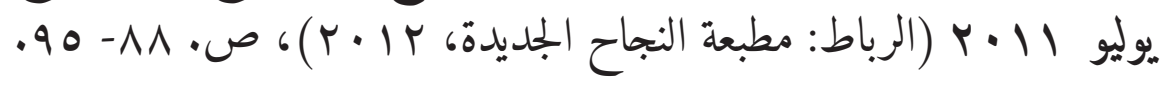
Ibnu Burdah, Islam Kontemporer: Revolusi dan Demokrasi (Malang: Interns Publishing, 2014). Al-Jämi'ah, Vol. 52, No. 2, 2014 M/1435 H 
وأما الأحزاب السياسية في دول الربيع العربي -نزن نريد هنا- فهي

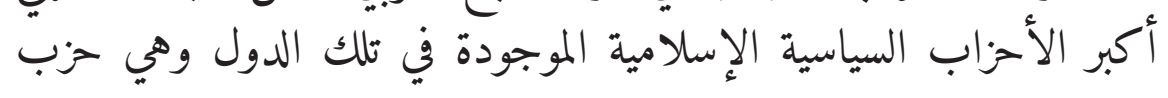

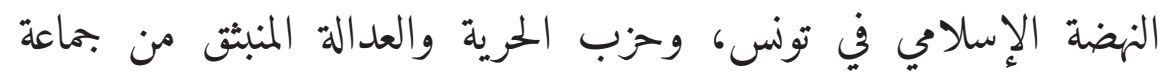

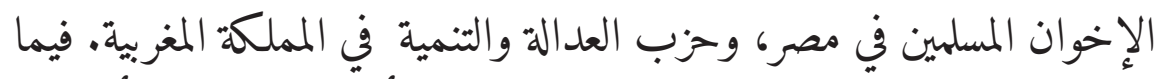

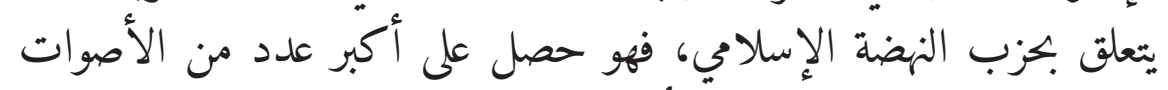

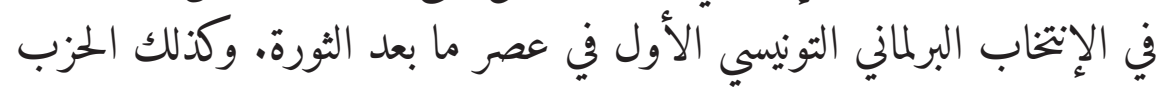

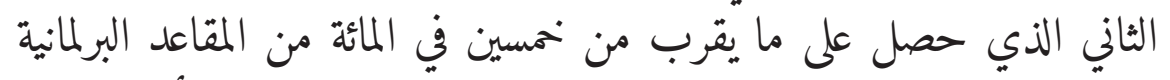

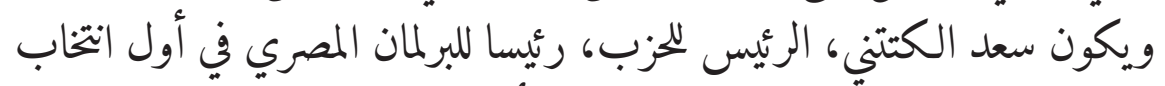

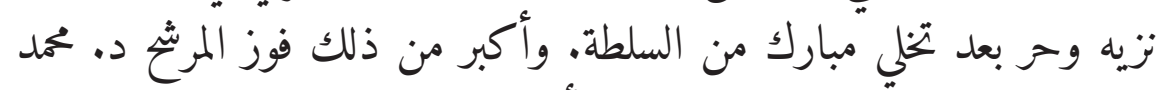

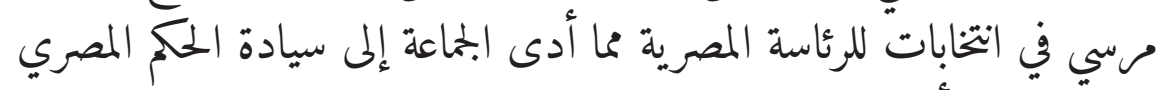

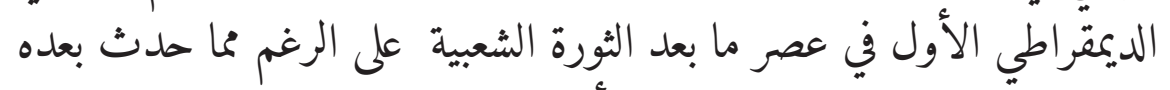

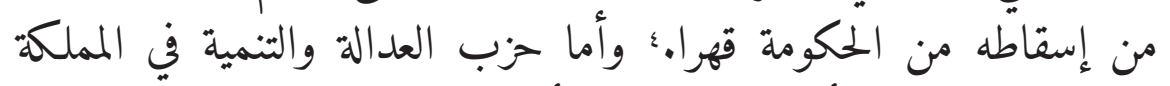

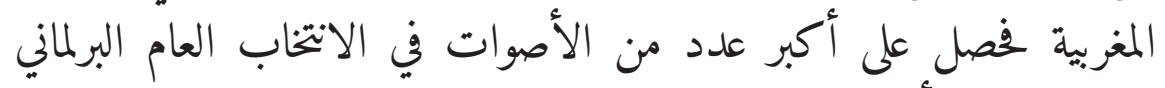

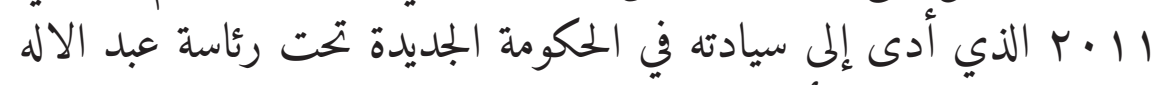

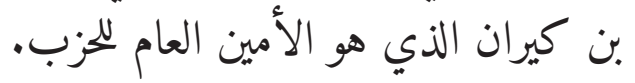

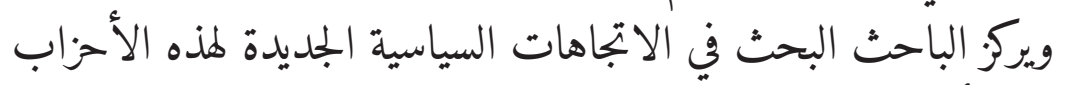

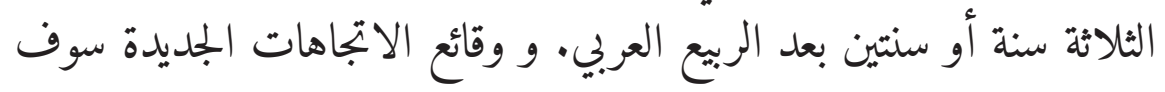

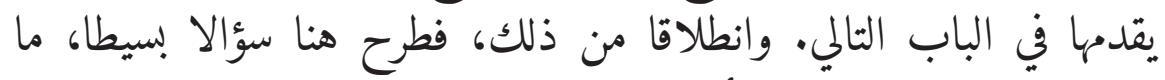

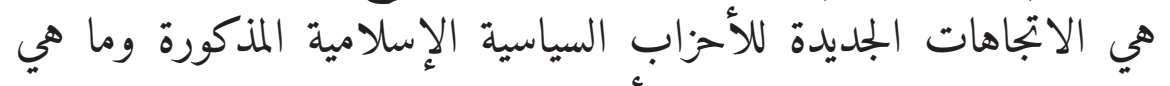

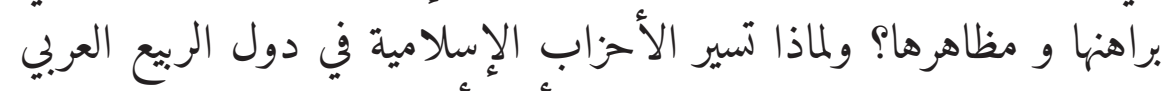

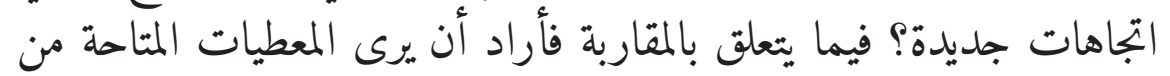

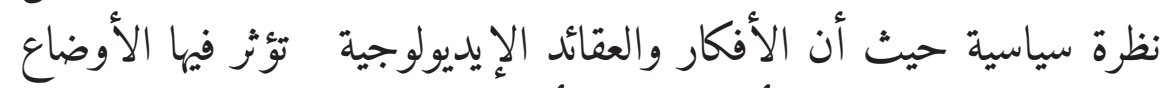

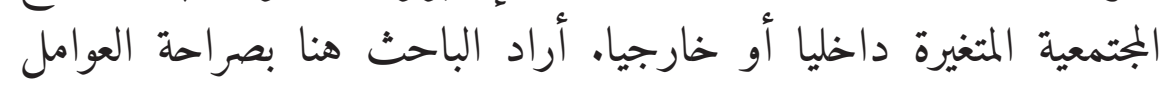
الحزبية الداخلية والعوامل خارجها دولة وإقليمية وعالميا.

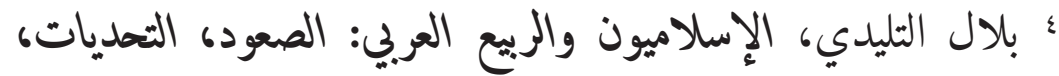
462

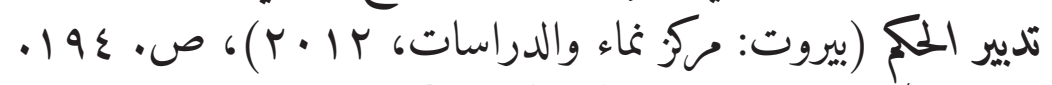


وهذا البحث مكتبي في الأساس حيث يتناول المعطيات من المصادر

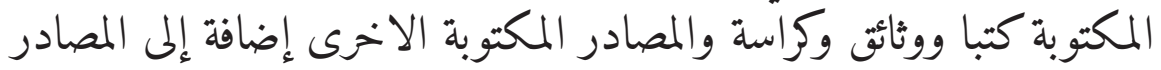

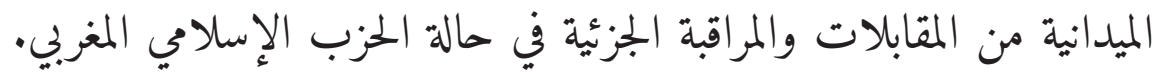

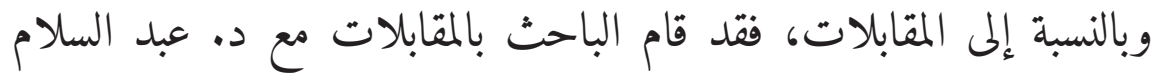

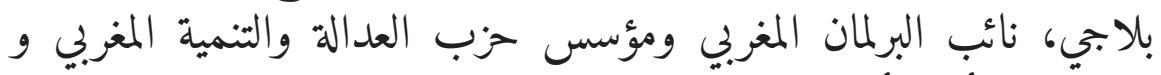

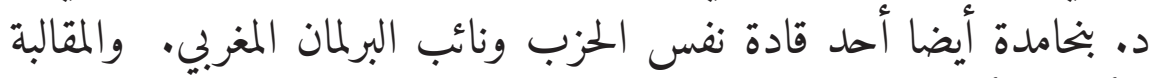

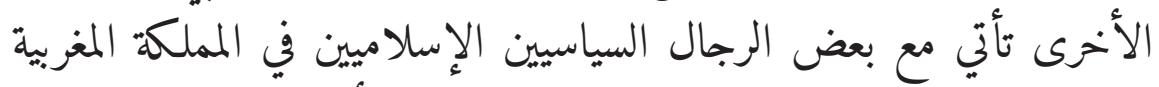

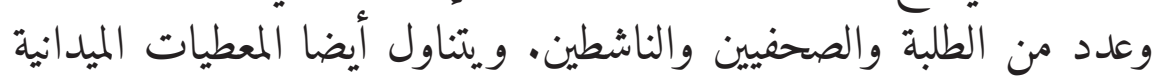

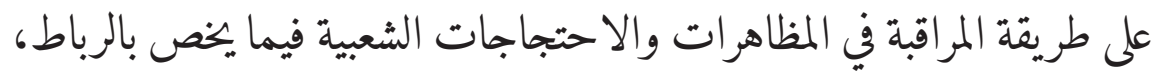

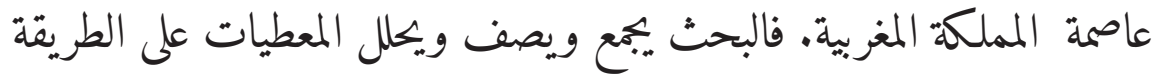

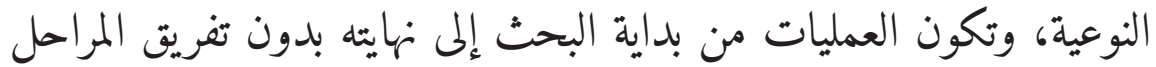

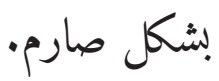

\section{التحرك إلى الاعتدال الإيديولوجي}

يقصد بالإعتدال الإيديولوجي هنا الاعتدالئ الإلئال في الأفكار السياسية

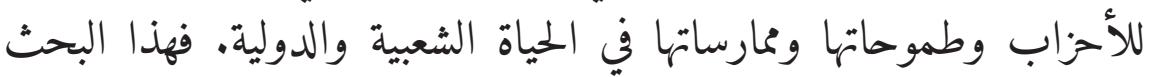

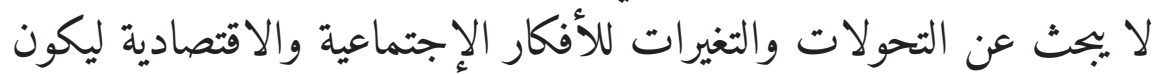

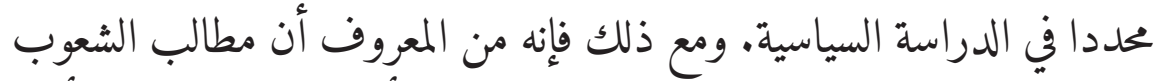

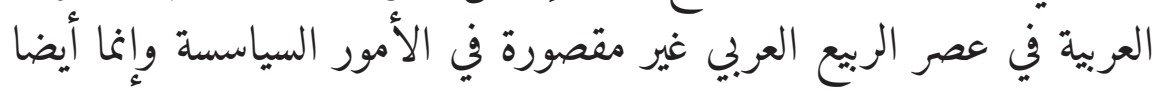

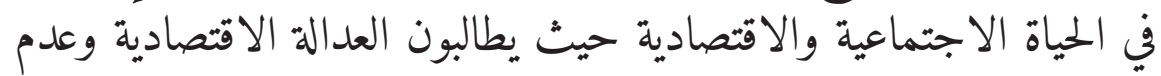

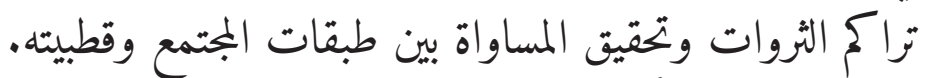

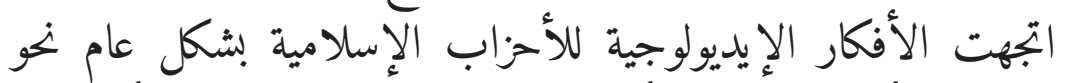

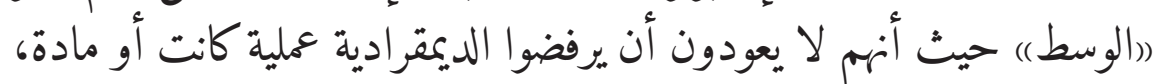

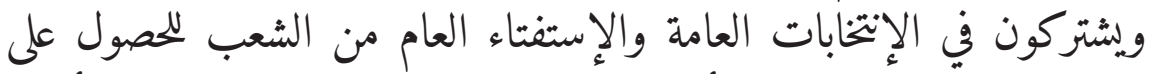

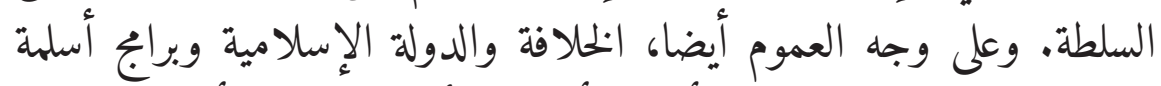

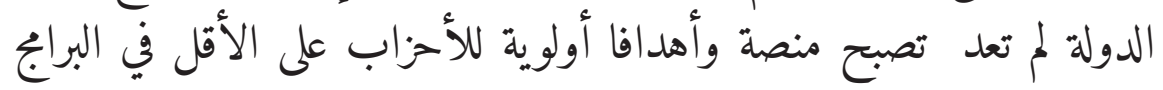


Ibnu Burdah

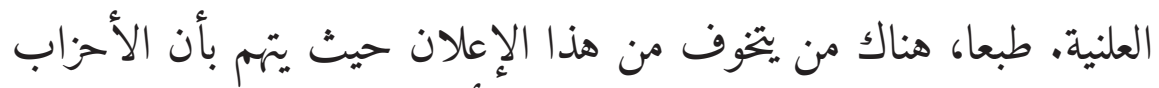

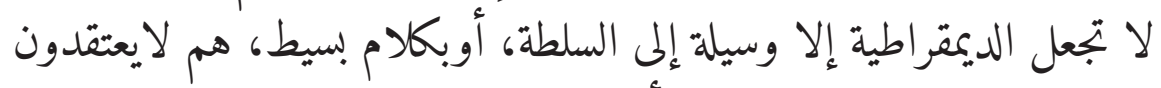

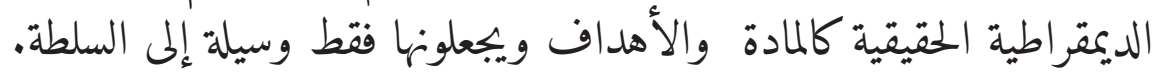

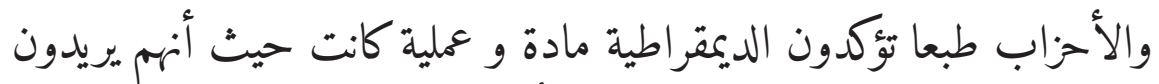

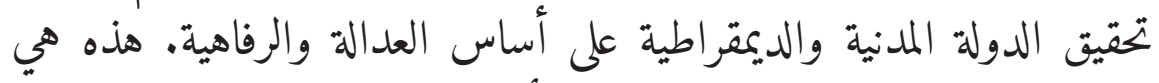
بعض البيانات والتصريحات من هذه الأحزاب كما يلي:

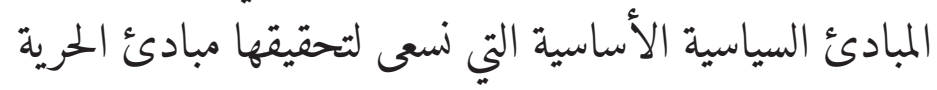

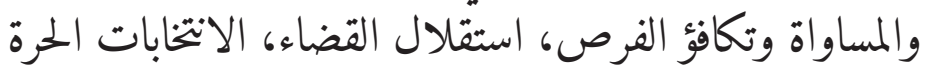

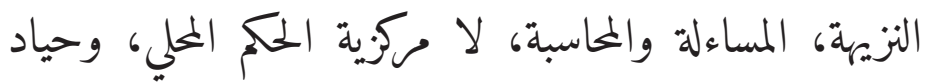

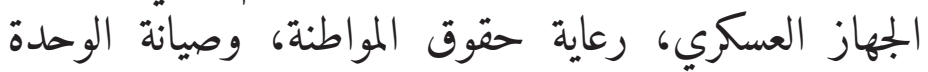
الوطنية، تفعيل دور الأفراد والمجتمع المدني. الموفي المطنة

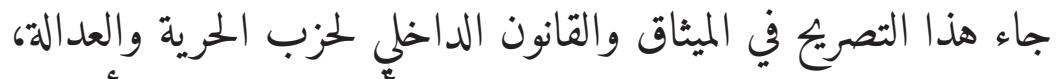

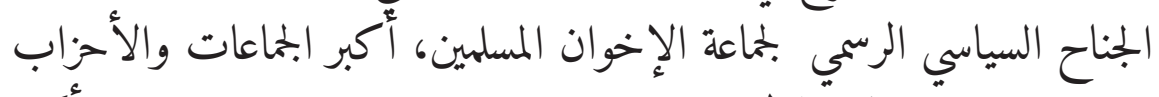

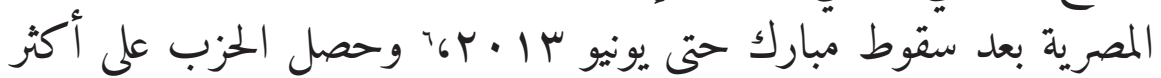

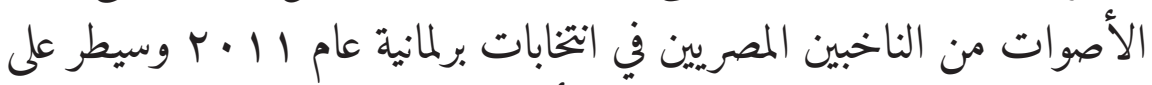
SV

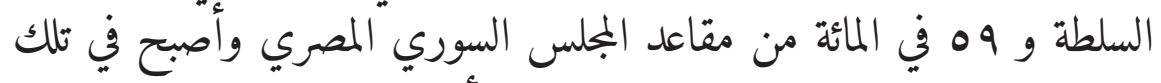

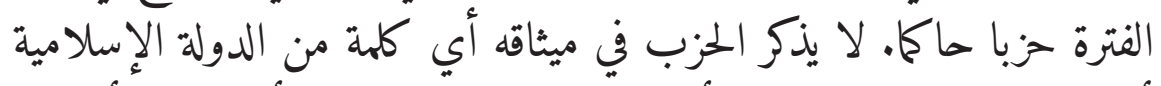

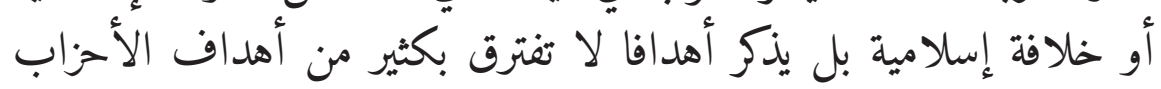

• نص برناجج حزب الحرية والعدالة (قاهرة: حزب الحرية والعدالة،

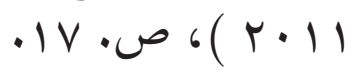

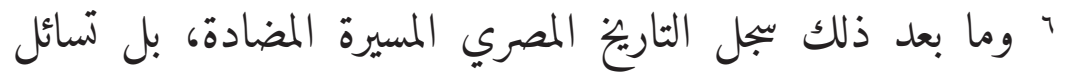
بعض الباحثين عن فشل البديمقراطية في المنطقة، انظر مثلا:

Maogoto, J.N. and A. Coleman, “The Arab Spring's Constitutional Indegestion: Has Democracy failed in the Middle East?”, Liverpool Law Review, vol. 35, no. 2, 2014, pp. 105-34. 
(العلمانية) وهي الحرية والمساواة وتكافؤ الفرص للجميع في الشئون السياسية

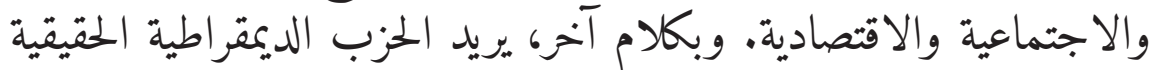

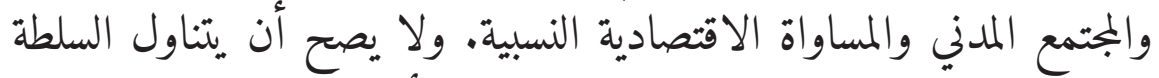

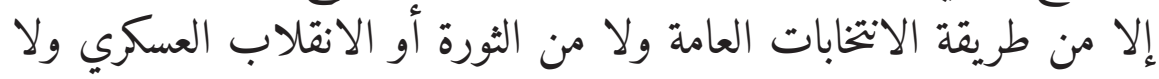
من التبريرات الدينية. فيما يتعلق بنظام الحكم، فيحدد الحزب الفئهل الفصل في السلطات التشريعية

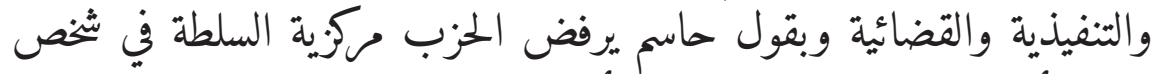

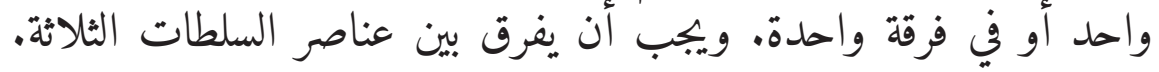

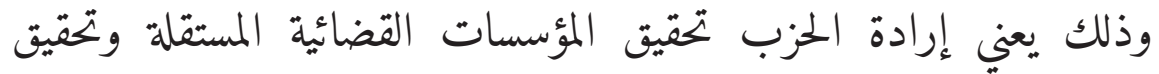

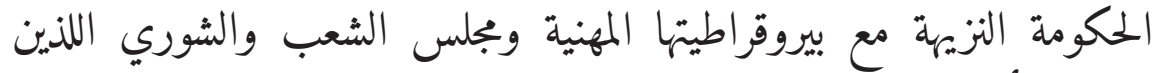

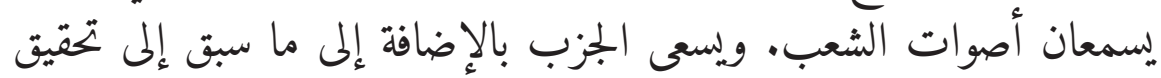

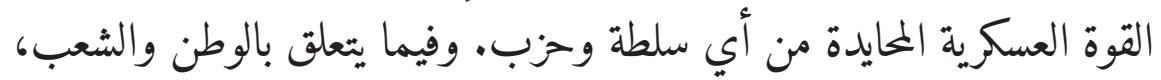

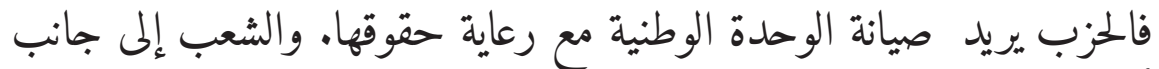

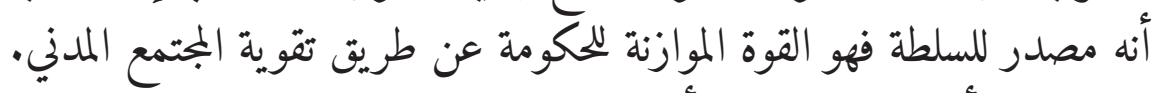

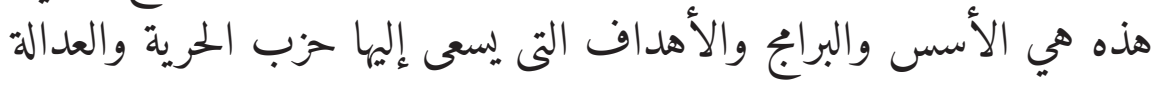

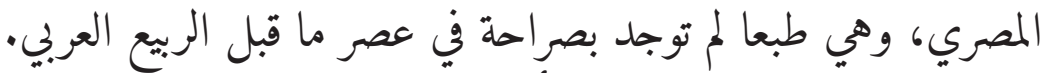

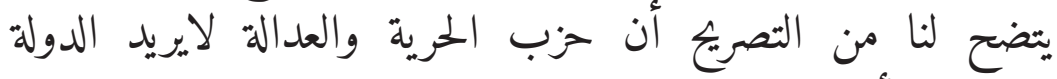

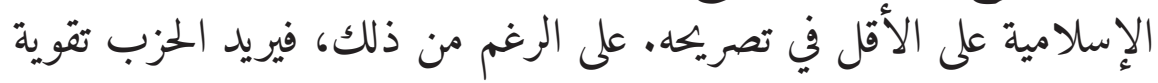

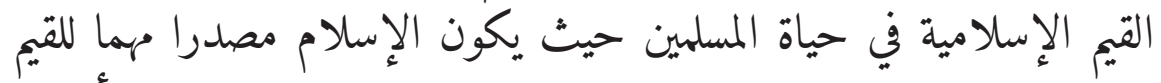

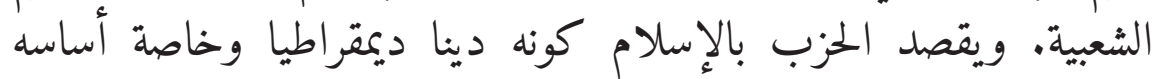

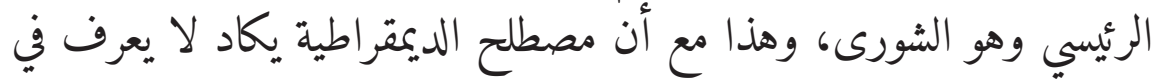

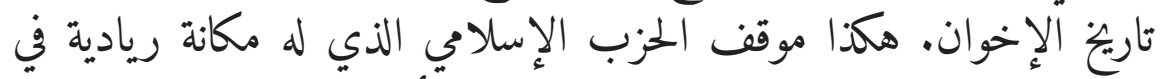

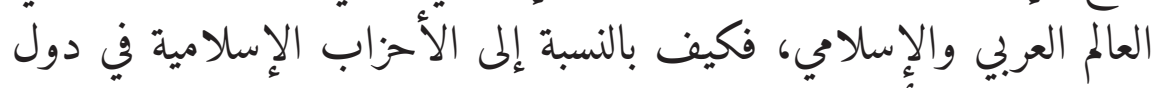

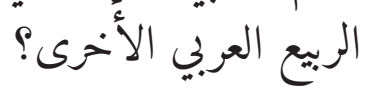
ورد في تصريح موقع رسمي في الميثاق والقانون الداخلي لحزب النهضة التونيسي ما يلي: 
Ibnu Burdah

حركة النهضة التونسية : هي حركة إسلامية وسطية ،معتدلة

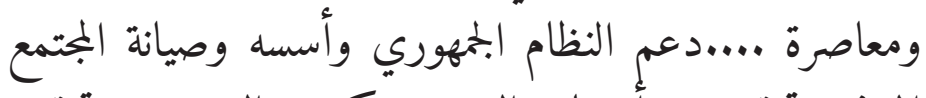

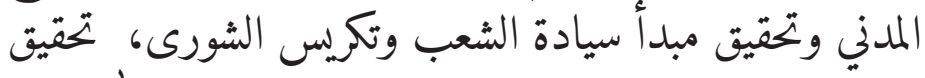

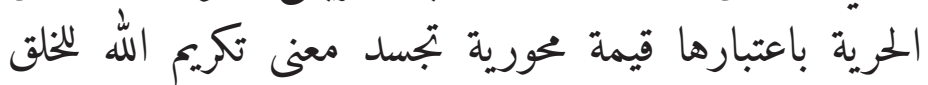

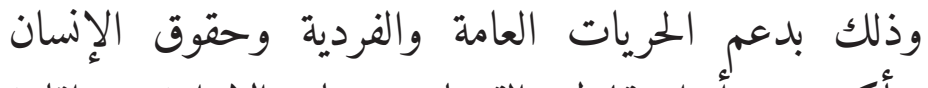

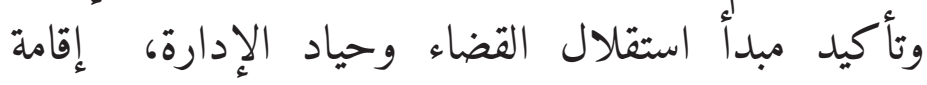

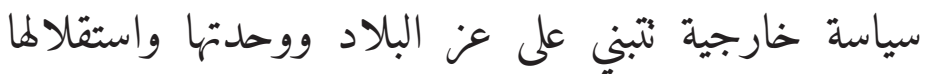

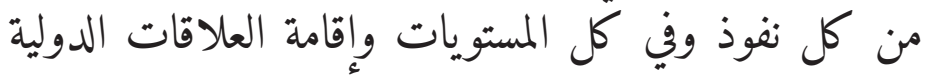

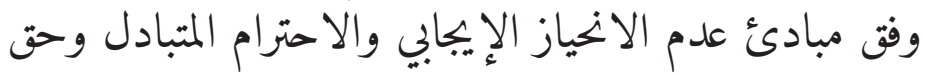

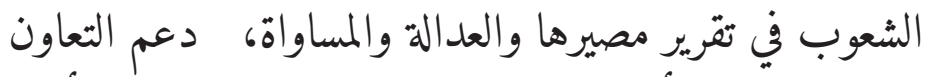

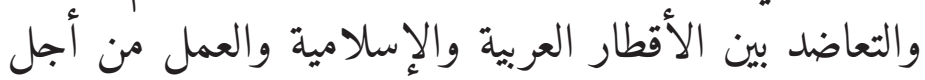
تكافلها ووحدتها.

حزب النهضة التونيسي هو الفائز فى الانتخابات البرلمانية التونسية الأولى ألى

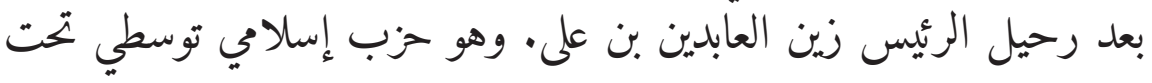

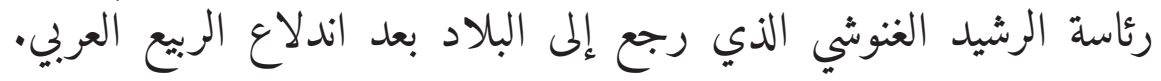

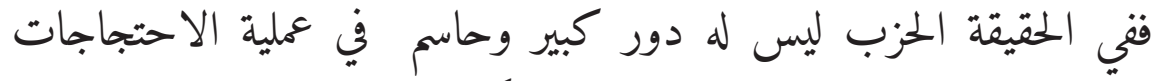

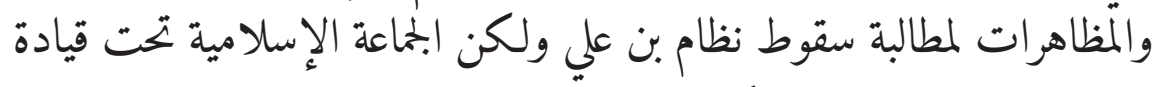

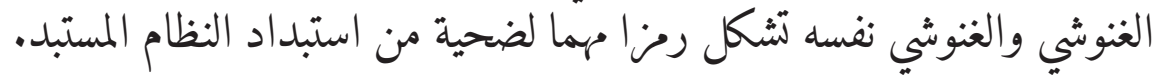

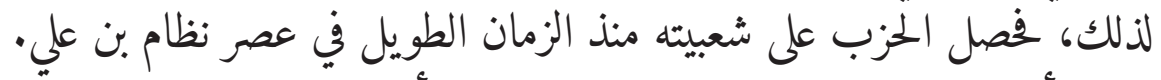

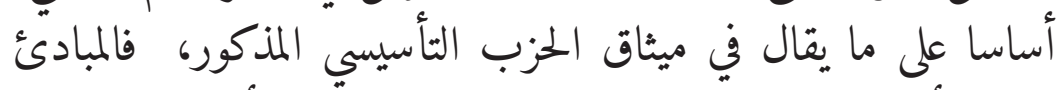

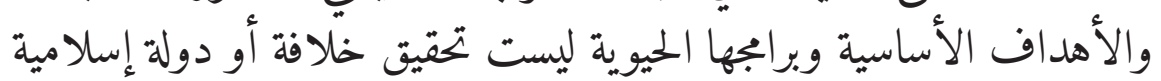

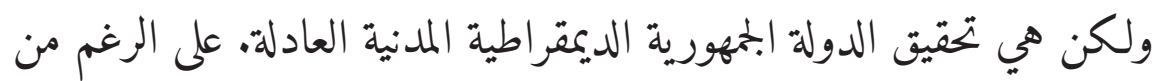

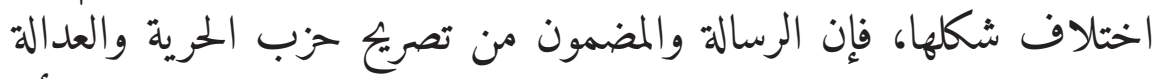

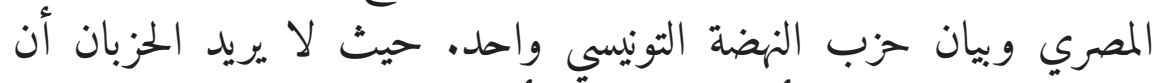

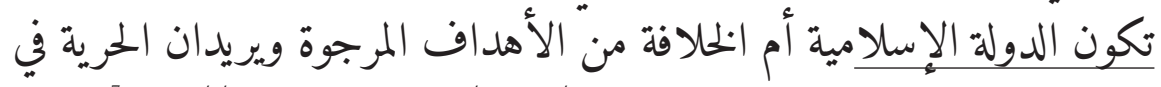
2014. 


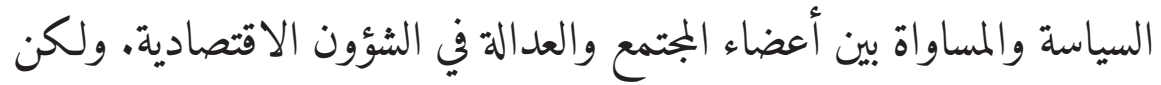

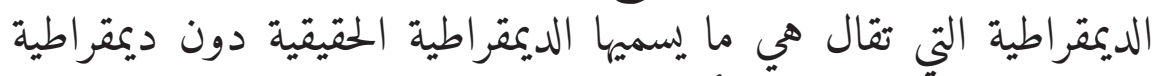

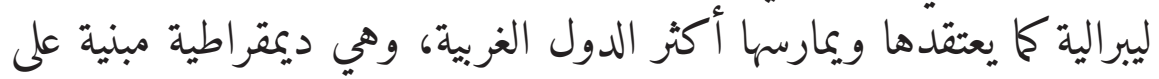
الشورى:

كما يؤمن الحزب بأن الشورى هي جوهر الديمقراطية، وهي

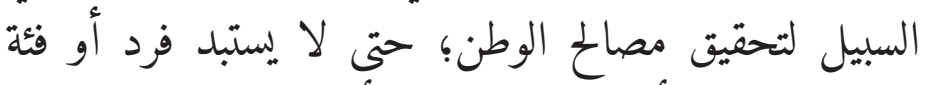

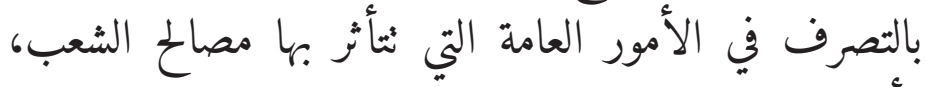

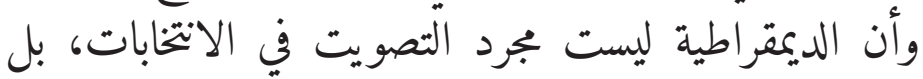

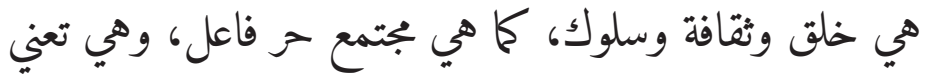

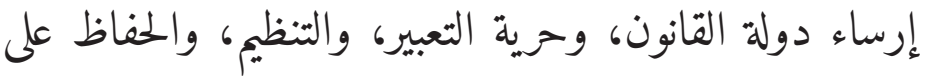

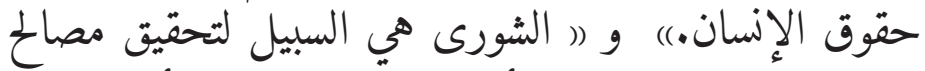

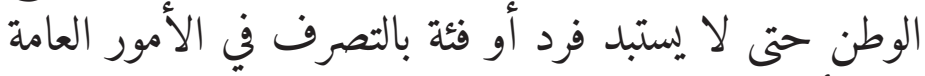

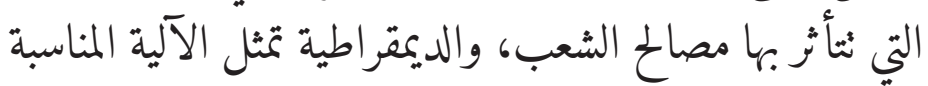

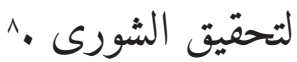

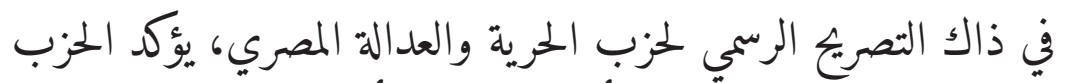

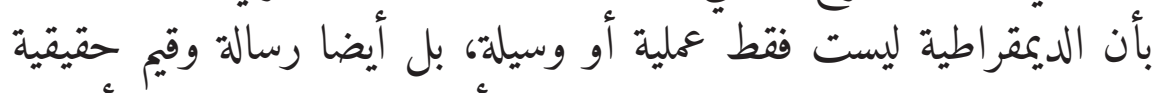

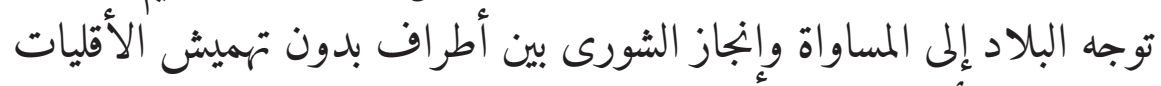

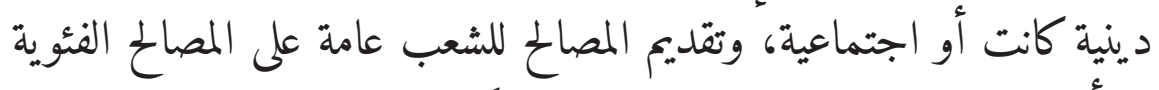

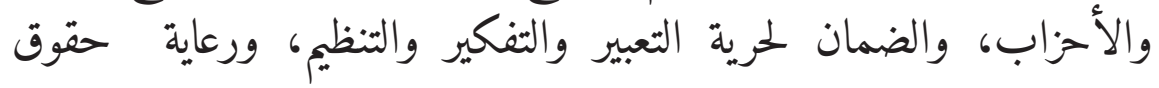
الإنسان. هذه هي تسمى بالديمقراطية الحقيقية.

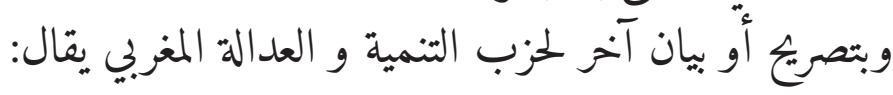

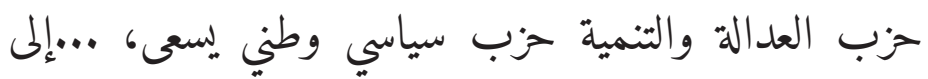

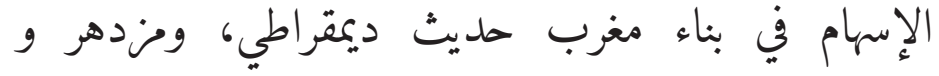

^ نص برناجج حزب الحرية والعدالة (قاهرة: حزب الحرية والعدالة، 
Ibnu Burdah

متكافل. مغرب معتز بأصالته التاريخية ومسهم إيبابيا في

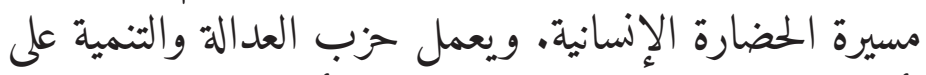

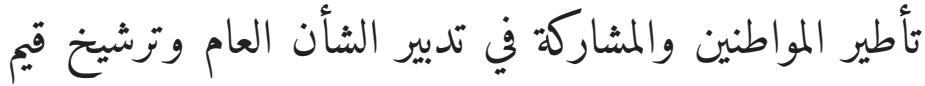

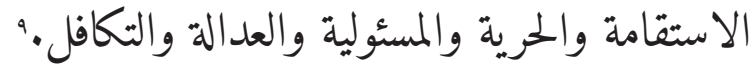

حزب العدالة والتنمية هو أكبر الأحزاب السياسية في المملكة

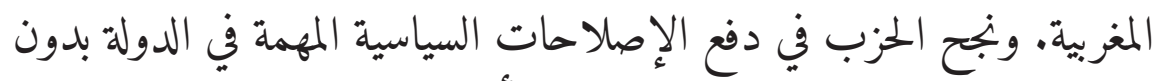

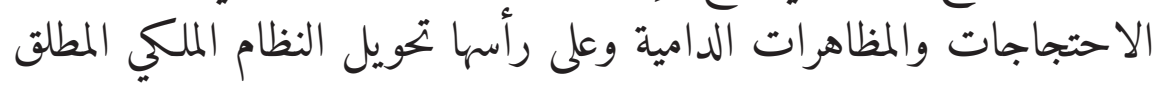

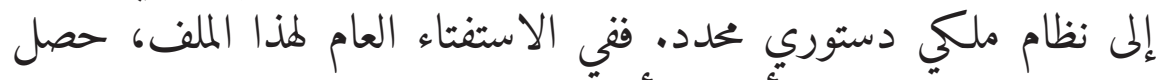

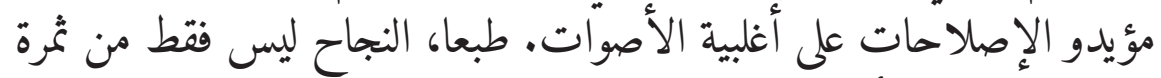

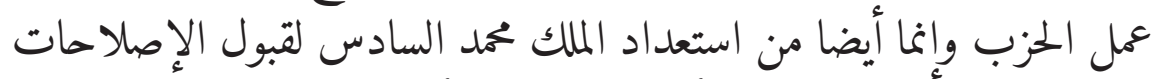

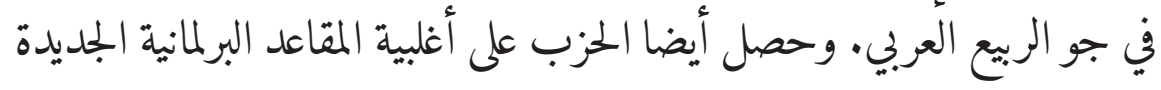

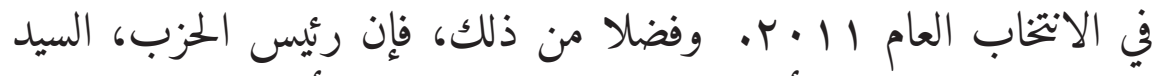

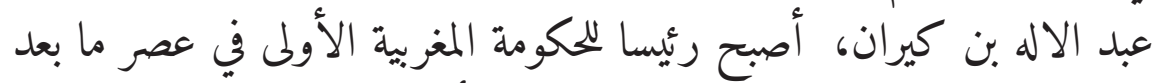

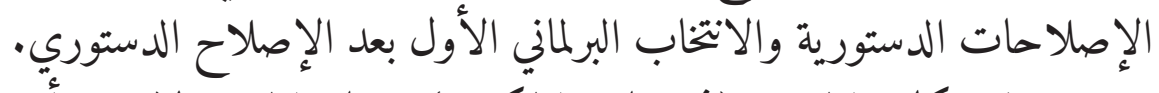

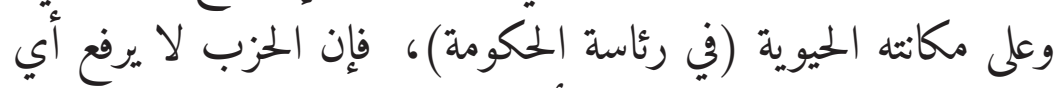

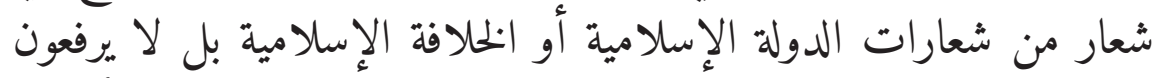

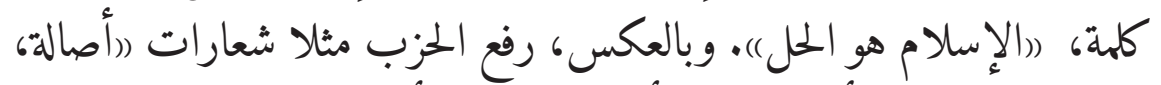

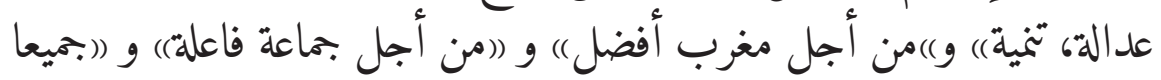

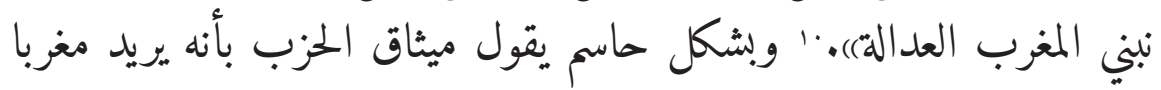

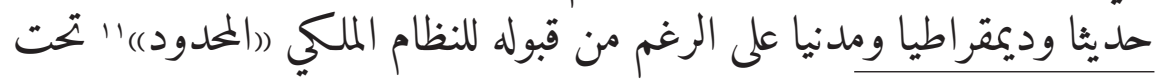

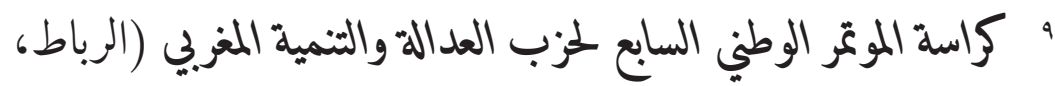

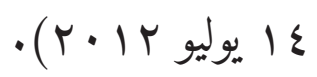

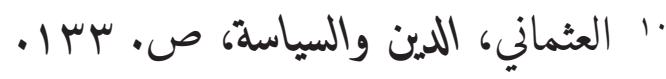

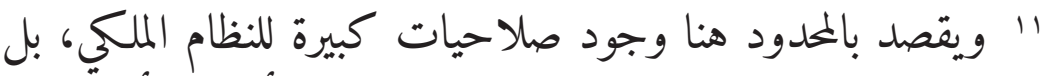

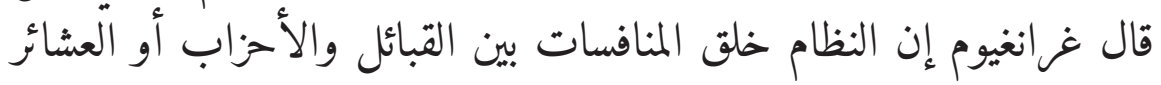

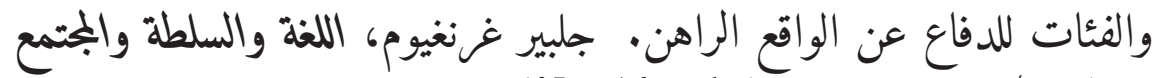
468 Al-Jamiiah, Vol. 52, No. 2, 2014 M/1435 H 
إمارة المؤمنين الملك محمد السادس بن حسن. لفظ إمارة المؤمنين يفيد ولاية

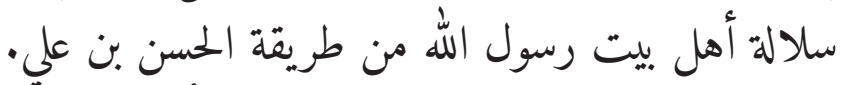

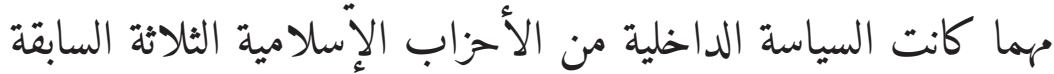

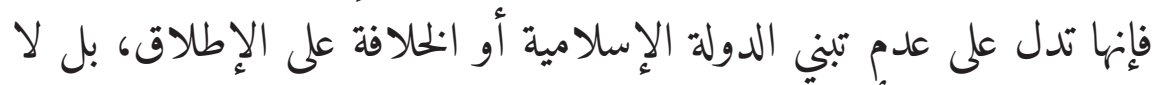

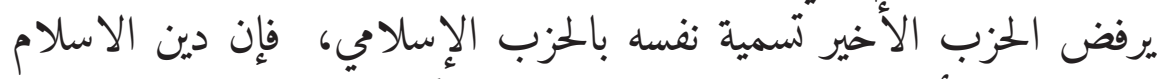

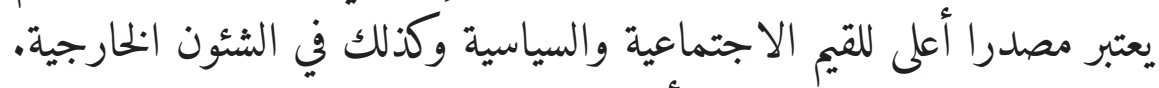
تابع القطعة التالية من ميثاق الأحزاب الإسلامية وتصريحاتها وبياناتها:

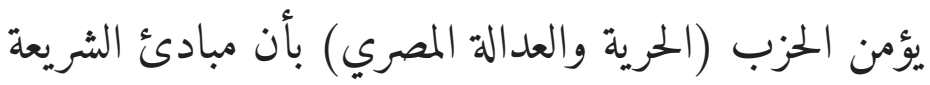

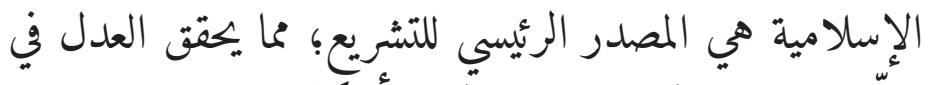

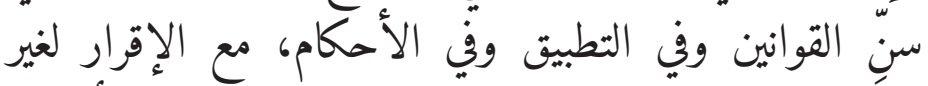
المسلمين بحقهم في التحاكم إلى شرائعهم، فيما يتعلق بالأحوال الأحوال الشخصية.ri

$$
\text { وفي نفس الكلمة، قال أحد قادة الحزب القبطي: }
$$

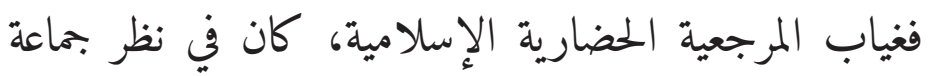

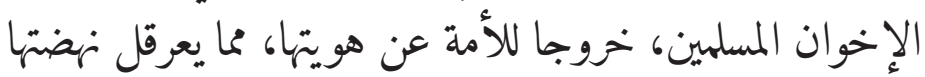

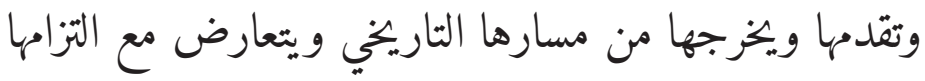

$$
\text { الديني." }
$$

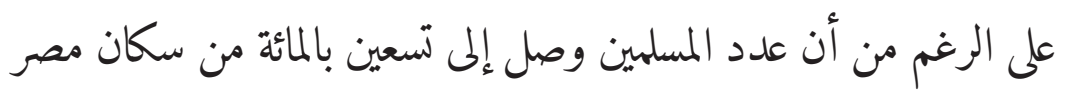

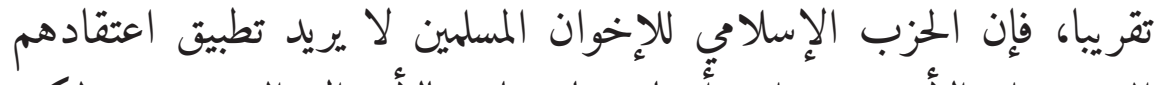

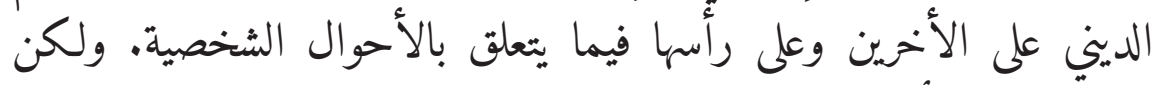
الحزب يحدد أن الإسلام هو مصدر رئيسي للقيم السياسية والإجتماعية فئية

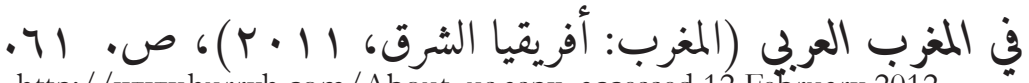

12 http://www.hurryh.com/About_us.aspx, accessed 12 February 2012.

rا رفيق حبيب، الدولتان: الإسلاميون والدولة القومية (قاهرة: دار

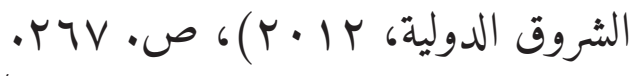


والاقتصادية. وذلك لا يعني أن الدولة دولة إسلامية ولكن الدين الإسلامي

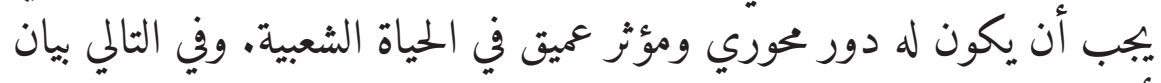
أخر لحزب إسلامي تونيسي عن الموضون:

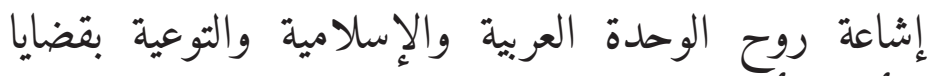

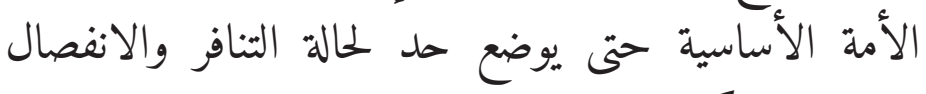

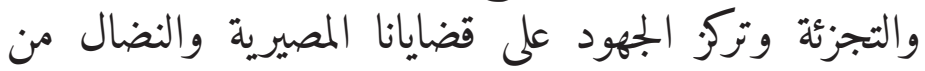

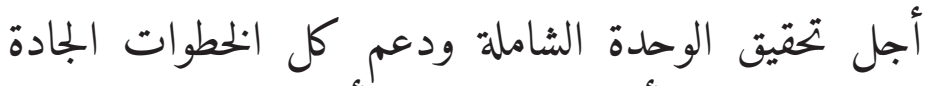

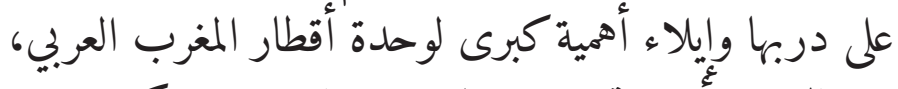

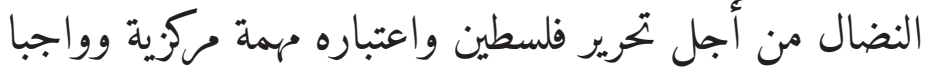

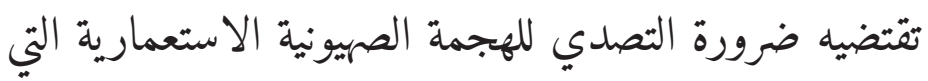

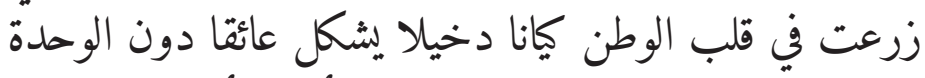

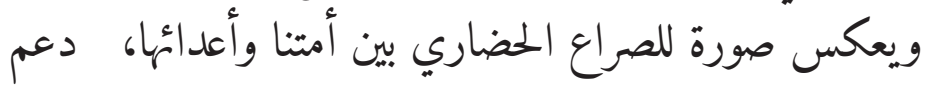

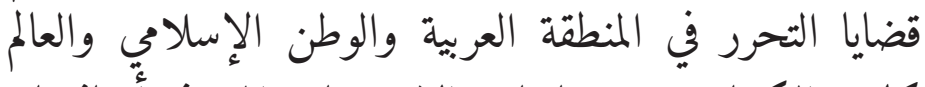
كافة والكفاح ضد سياسات الاستعمار والميز في أفضغانستان

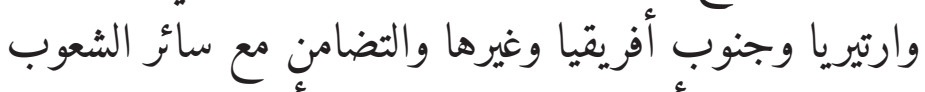

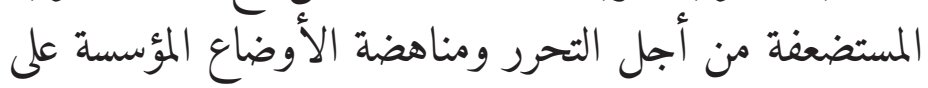

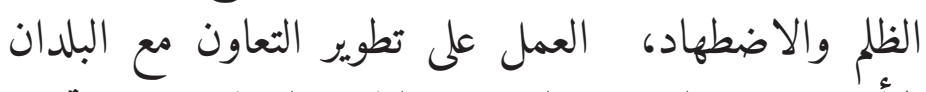

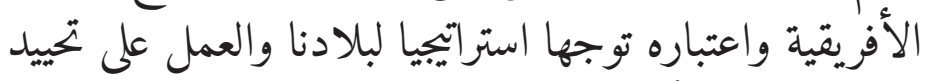

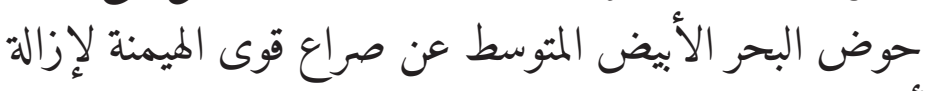

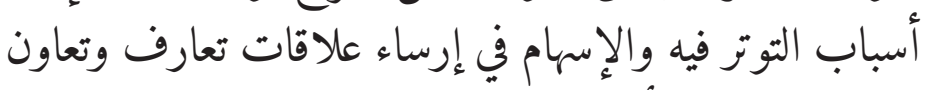

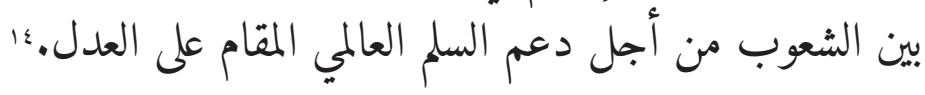
هذا النص من حزب النضة التونيسي يؤكد بأن التضامن والتعاون

\&' حزب النهضة هي أكبر الأحزاب السياسية بعد رحيل زين العابدين بن علي بعد الثورة الشعبية الواسعة. http://www.nahdha.info/arabe/Sections-artid-97.html, accessed 2 January 2012. 470 
بين الدول الإسلامية (الدول أغلبية سكانها مسلمون) يجب أن يكون محورا

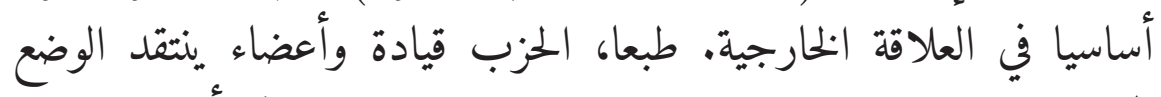

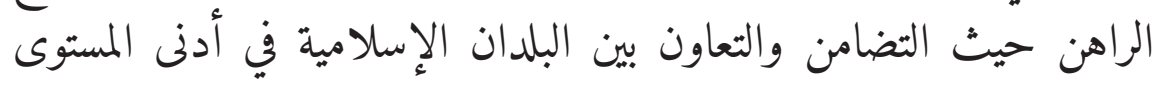

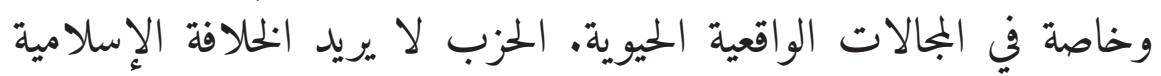

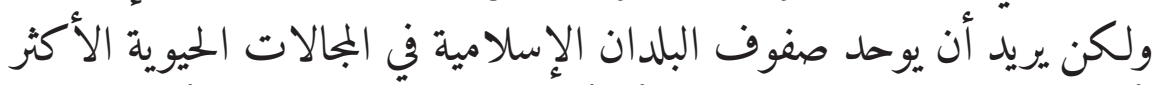

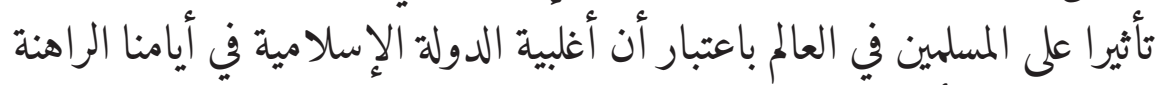

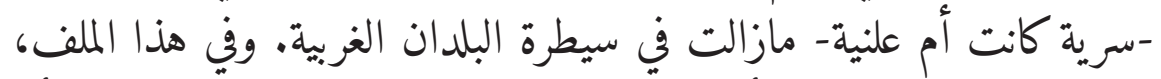

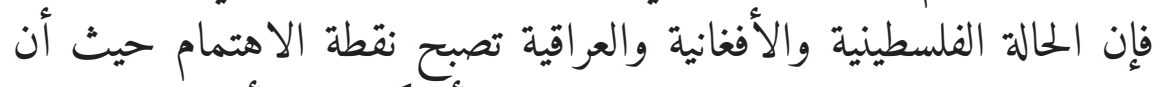

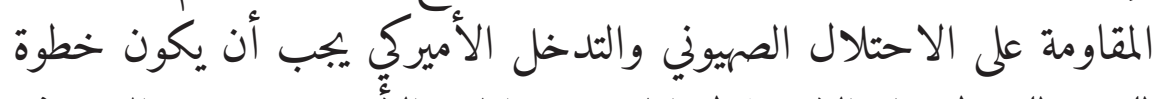

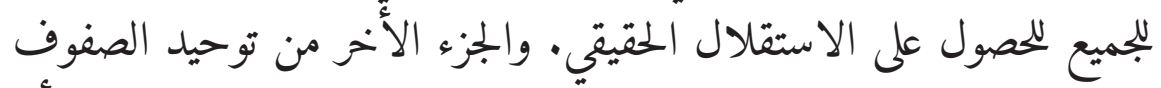

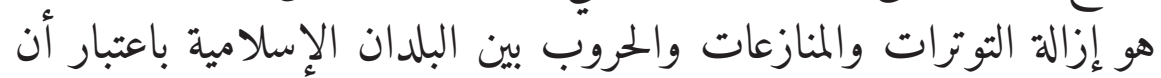

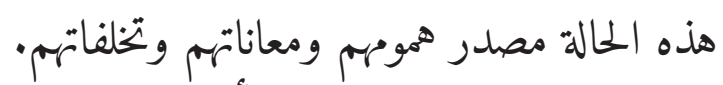

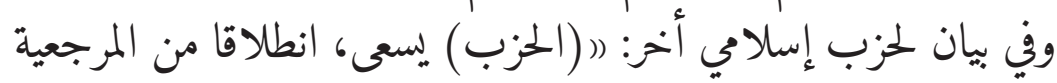

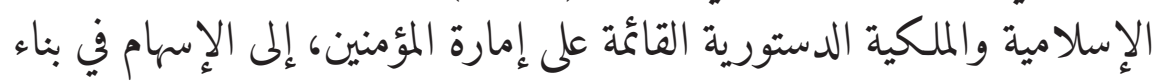

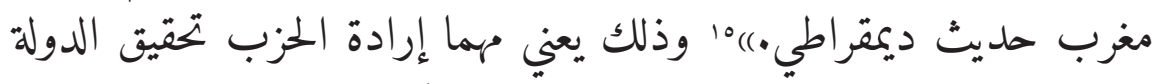

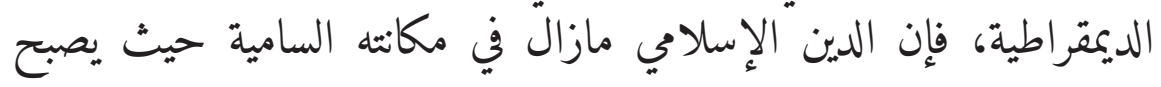

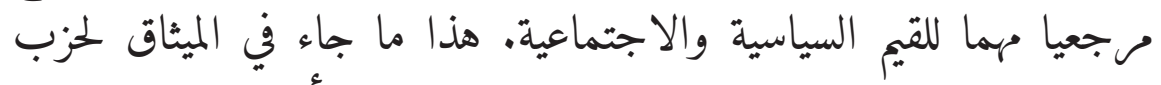

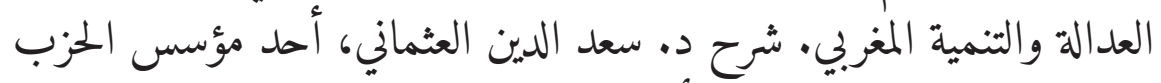
والرئيس السابق للمزب عن الأمر كما بيلي:

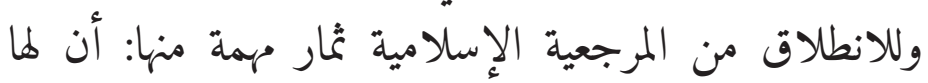

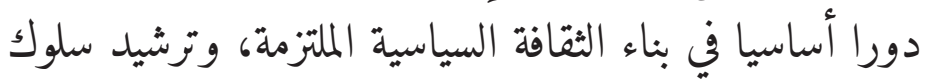
الفاعلين في الحياة السياسية، وذلك من خلال المافية تعزيز المسئولية

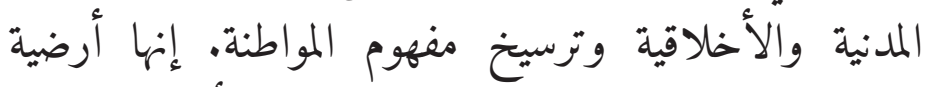
صلبة وحقيقية بمادتها القيمية والتشريعية والأخلاقية للقيام

10

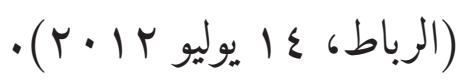


Ibnu Burdah

بالانجازات الكبيرة في مجال الديموقراطية وتكريم الإنسان ورعاية حقوقه والقيام بالإصلاحات السياسية الضرورية.ت17

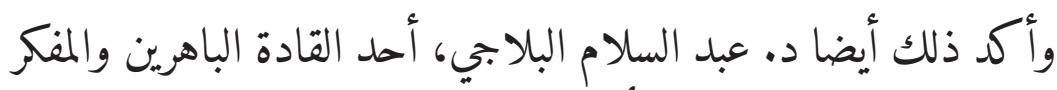

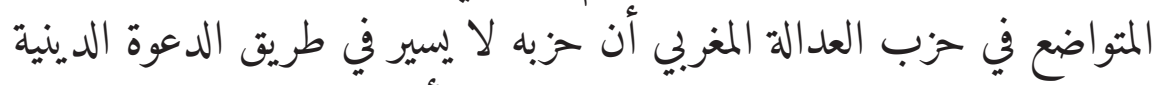

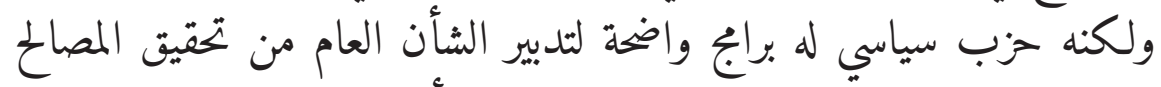

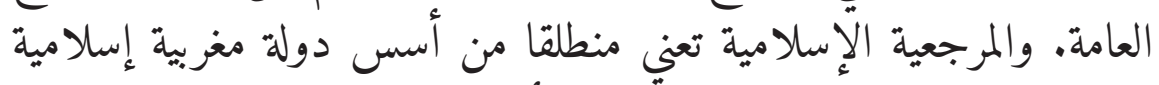

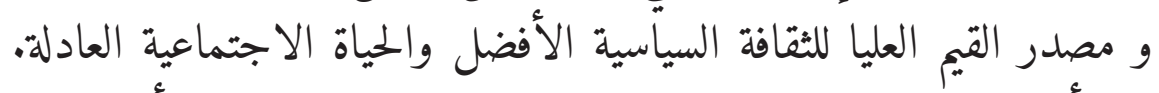

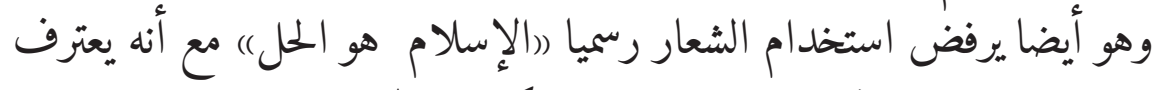

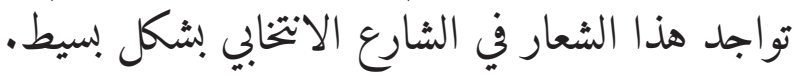

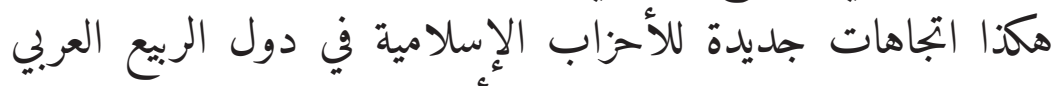

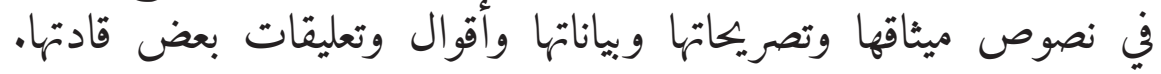

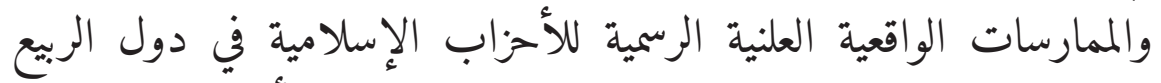

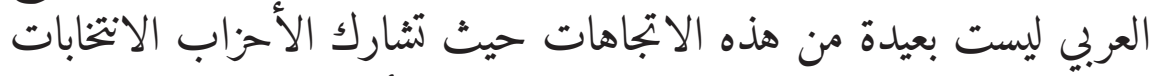

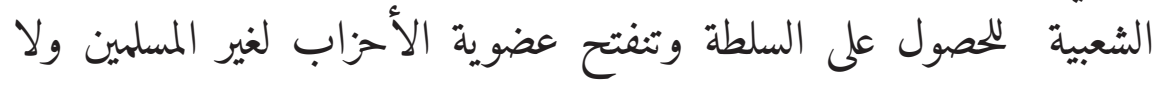

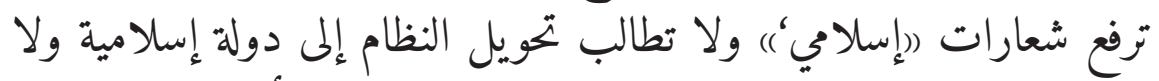

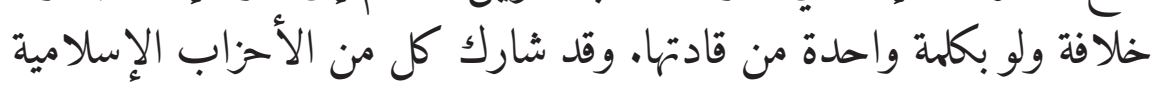

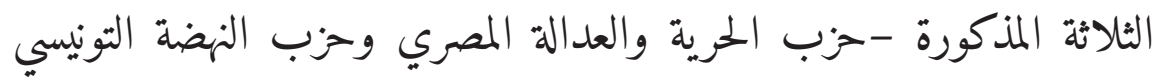

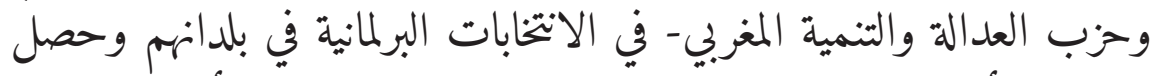

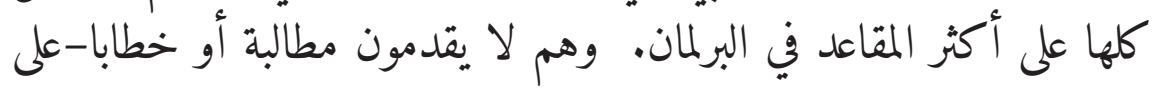

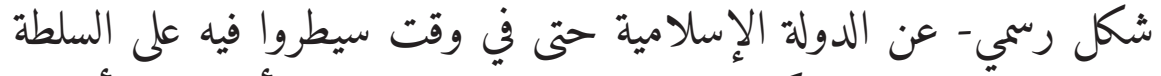

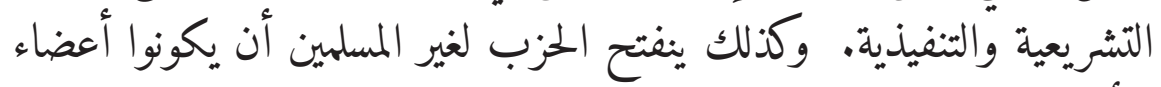

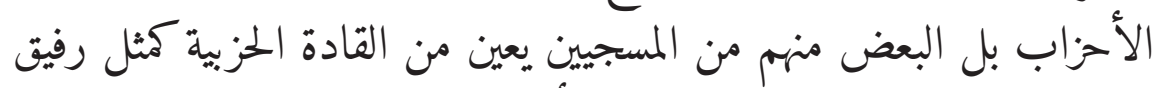

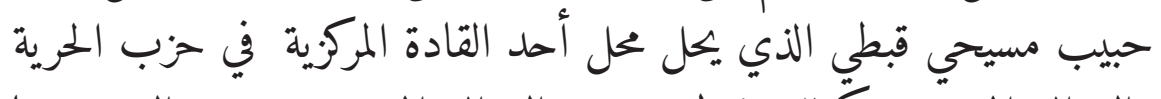

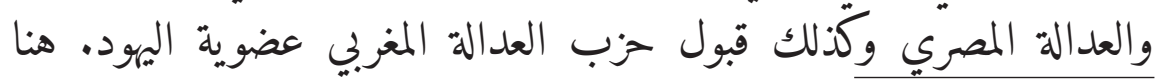

17 سعد الدين العثماني، الدين والسياسة: تمييز لا فصل (بيروت: المركز 
بعض المقتطفات التي ثتعلق بعضوية الحزب الإسلامي المغربي من كلام أحد قادته تعليقا لعضويته المفتوحة:

تنبنى العضوية في الحزب على أساس المواطنة والقبول بمرجعية المعادية

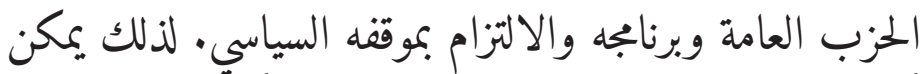

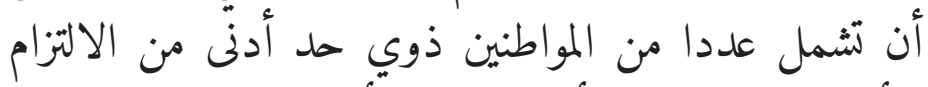

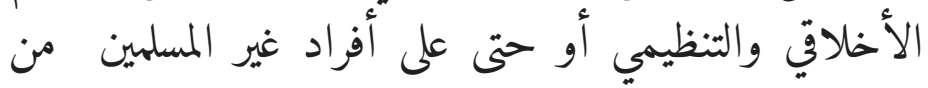

$$
\text { اليهود مثلا. الاخدان ون }
$$

\section{ت. الربيع العربي والتغيرات السياسية}

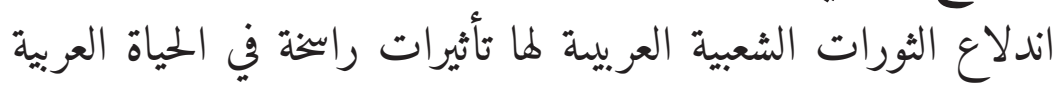

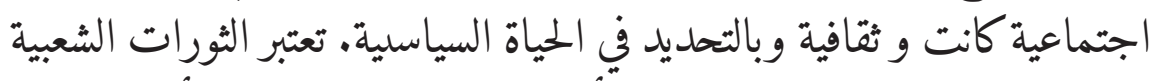

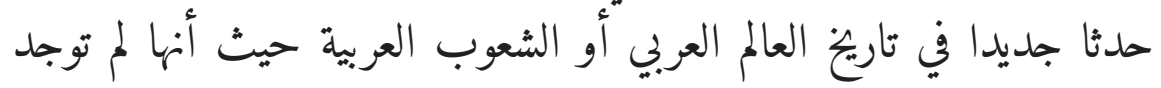

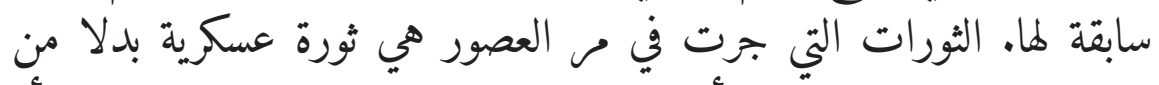

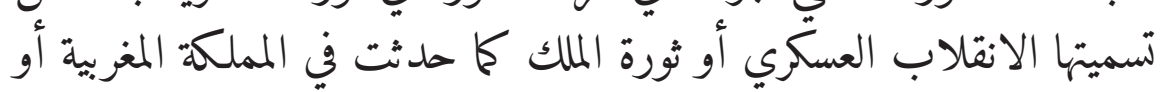

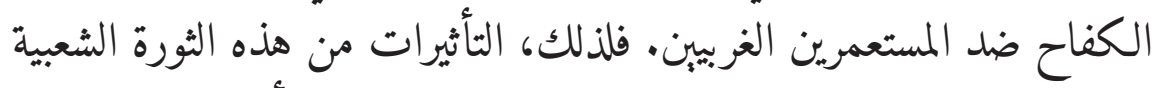

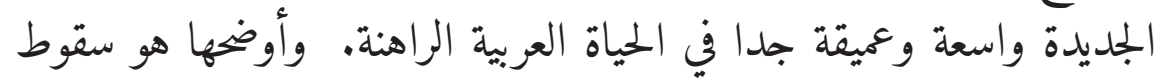

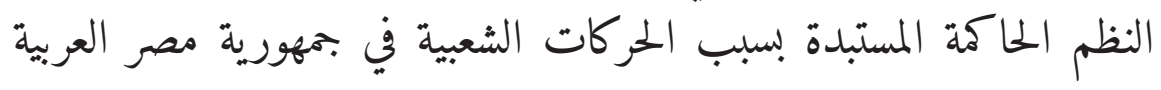
وتونس وليبيا واليمن. والنقطة المهمة الأخرى من التأثيرات هي ظهور الشعب كالعامل

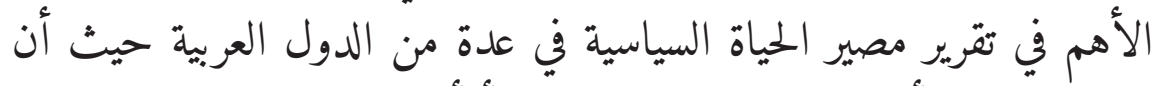

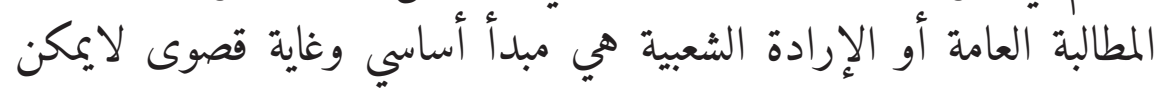

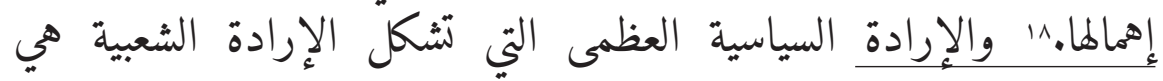

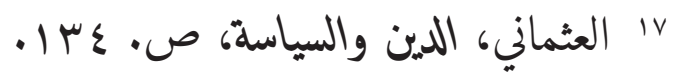

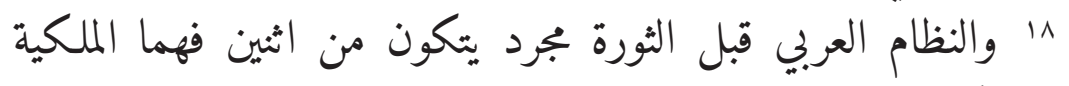

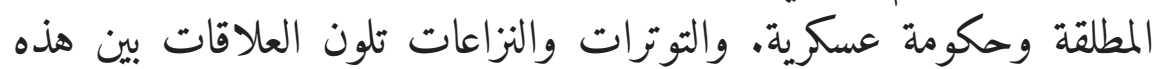
الدول. أنظر عن الموضوع فن: المطركة 
Ibnu Burdah

(رالديمقراطية)،"19 حيث تصبح الإرادة الشعبية المصدر الوحيد للسلطة. فهذا

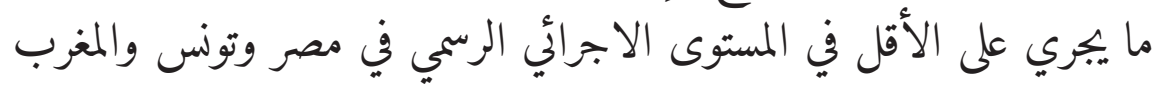

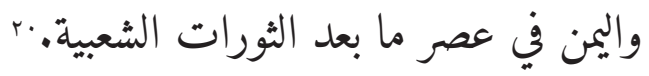

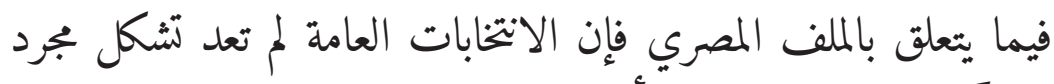

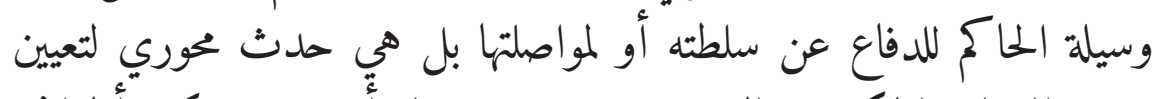

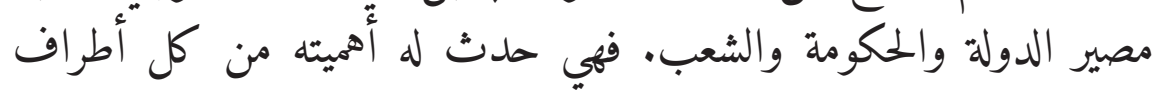

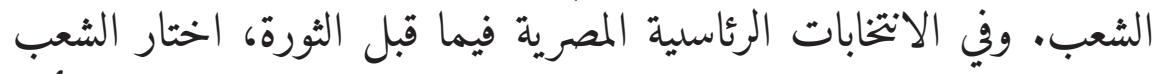

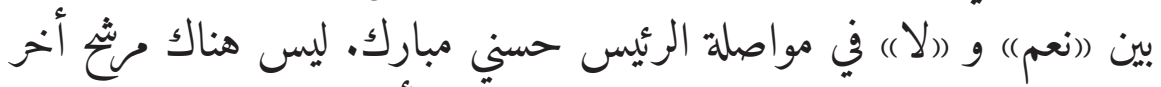

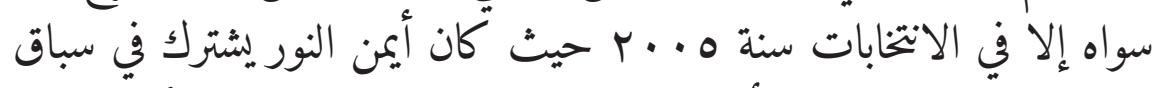

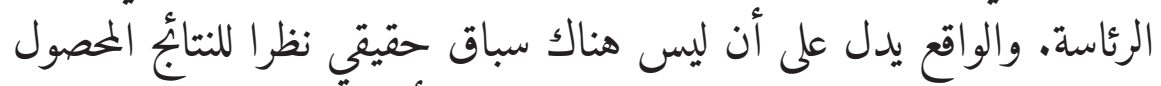

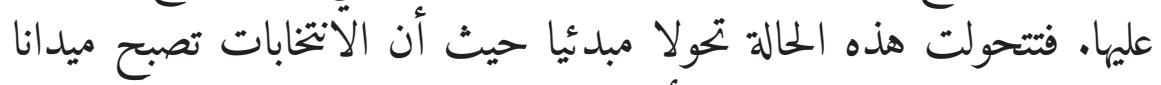

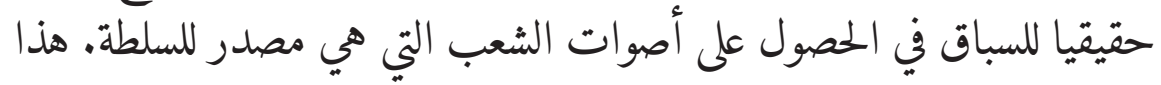

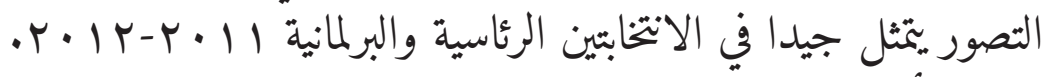

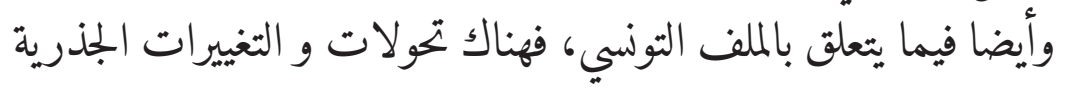

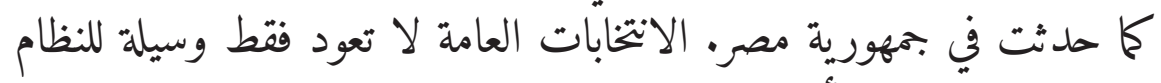

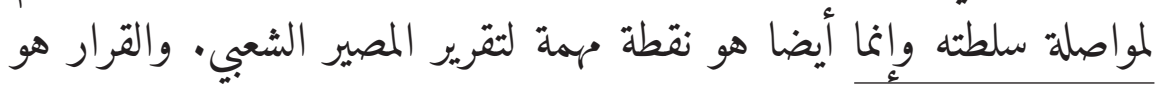

Ibnu Burdah, Konflik Timur Tengah: Aktor, Isu, dan Dimensi Konflik (Yogyakarta: Tiara Wacana, 2008).

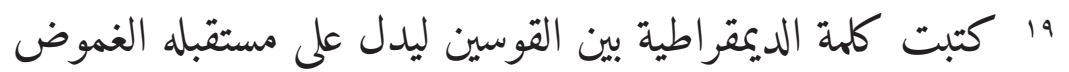

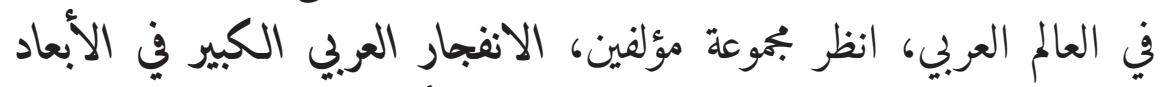

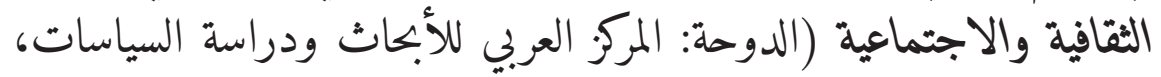

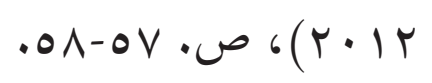

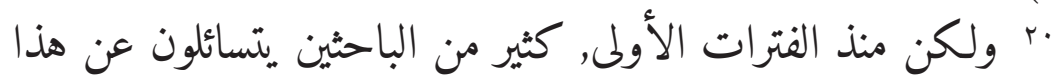

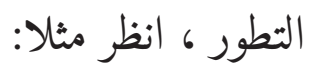

Y. Waghid and N. Davids, "On the (Im)possibility of Democratic Citizenship Education in the Arab and Muslim World", Studies in Pbilosophy and Education, vol. 33, no. 3, 2014, pp. 343-4.

474

Al-Jämiáa, Vol. 52, No. 2, 2014 M/1435 H 
قرار الشعب. على الرغم من أن تأثيرات التيارات الدينية قوية في العملية

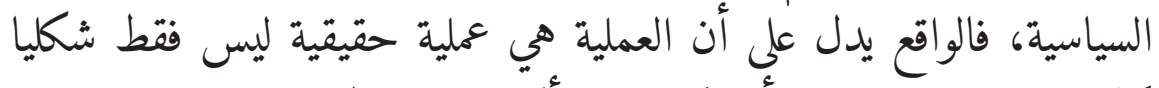

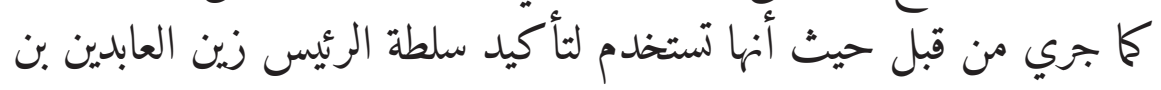

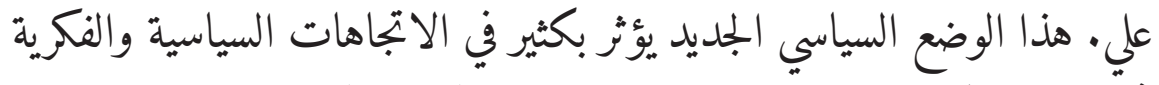

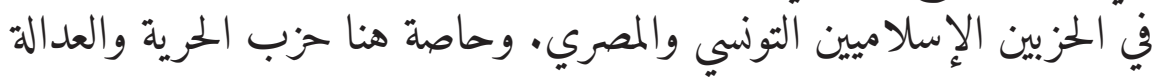

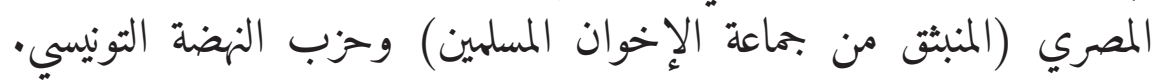

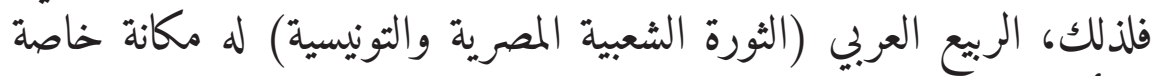

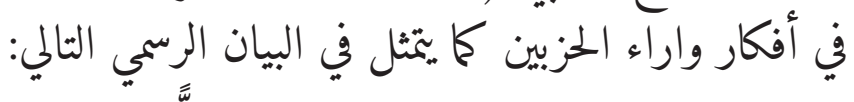

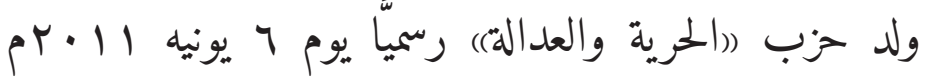

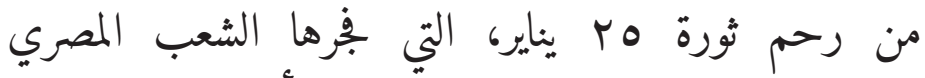

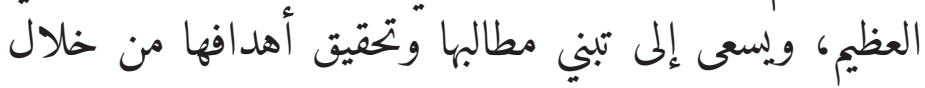

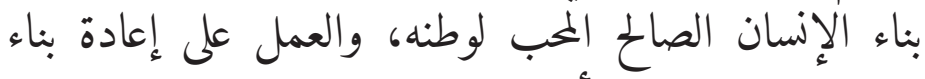

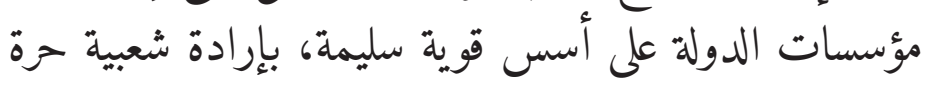

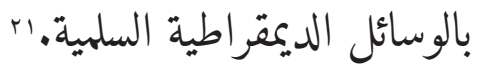

هذه الدمقرطة لا تخلو من انتشار الوسائل الإعلامية والإجتماعية

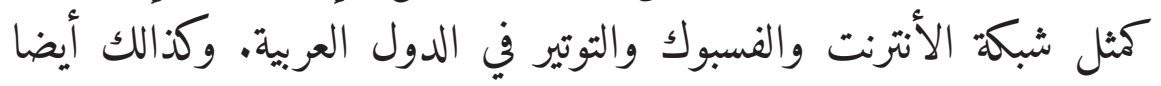

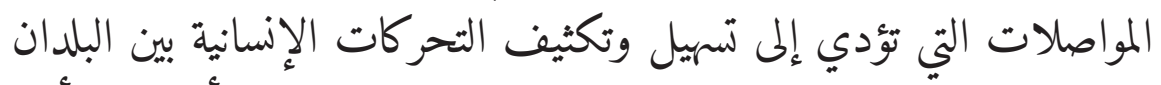

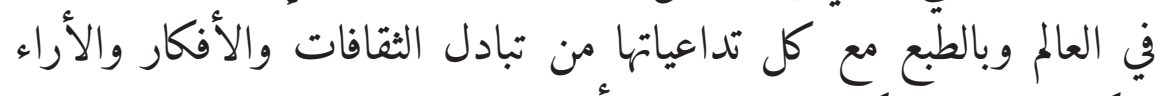

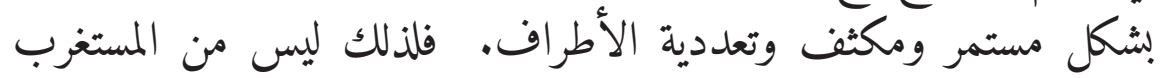

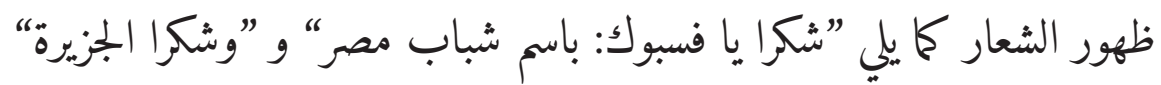

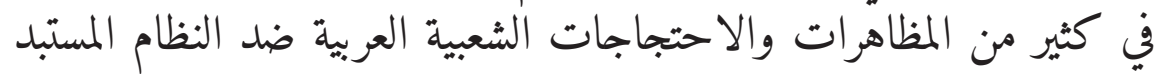

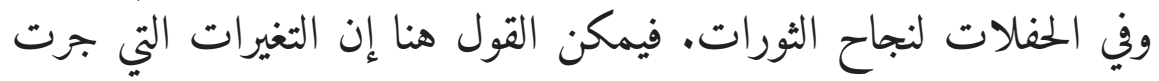
في بعض الدول العربية هي - كما يقول فوكوياما في نهاية التاريخ- باتي التئي

r كراسة الموتمر الوطني السابع لحزب العدالة والتنمية المغربي

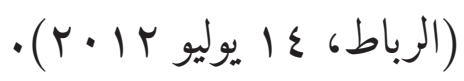


Ibnu Burdah

عمليات الدمقرطة في العالم.r م وبكلام أخر يمكن تصديق الرأي القائل بأن

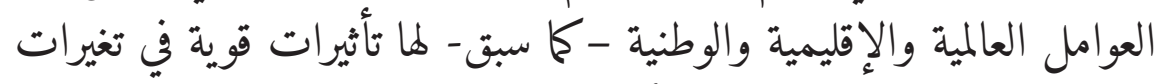

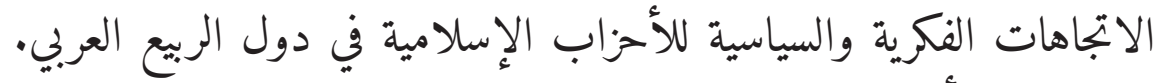

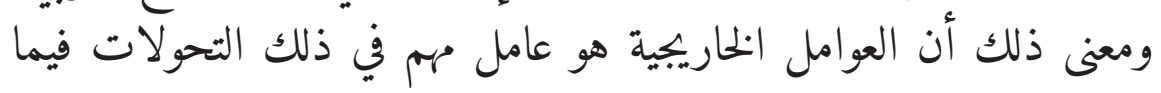

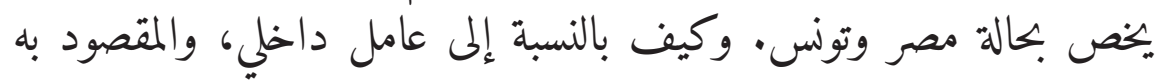

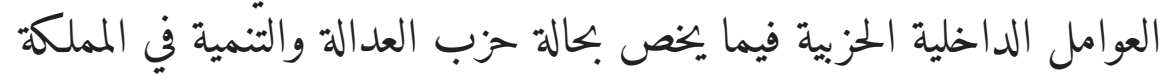
المغربية.

\section{ث. التطورات الداخلية}

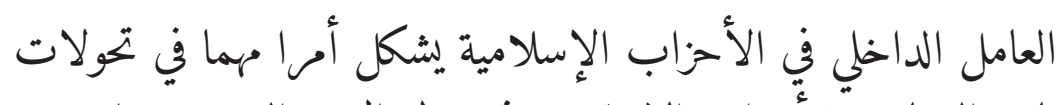

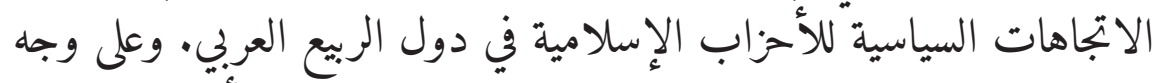

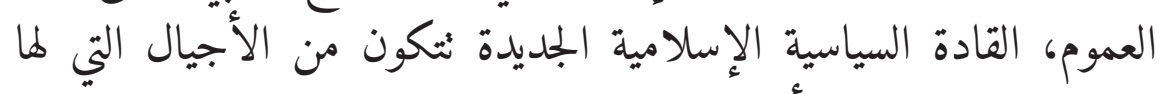

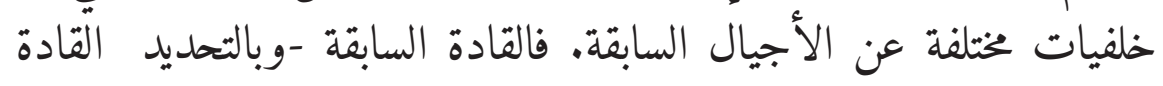

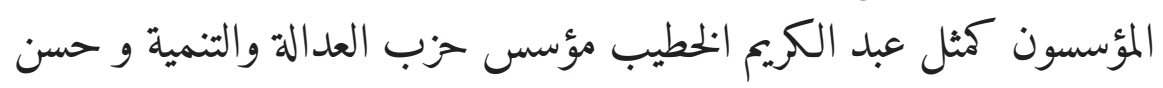

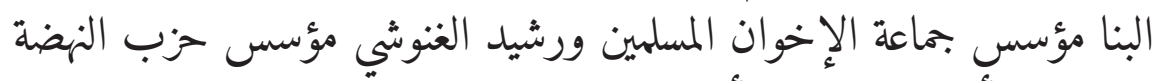

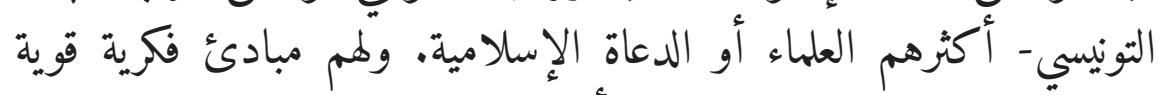

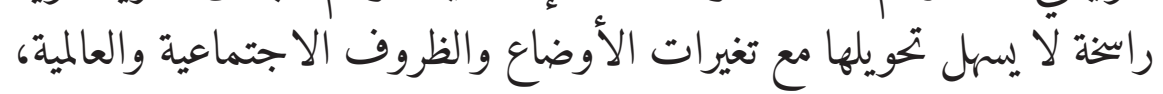

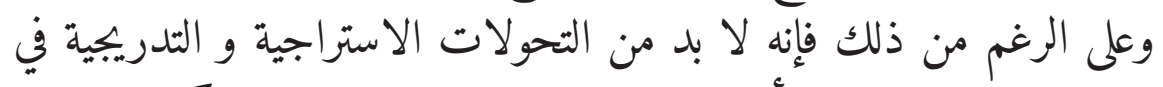

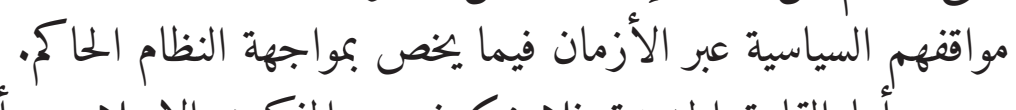

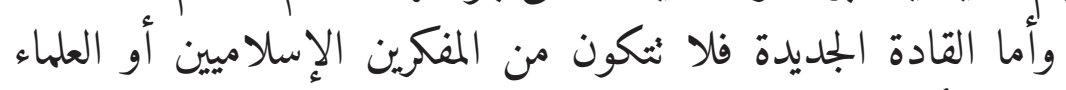

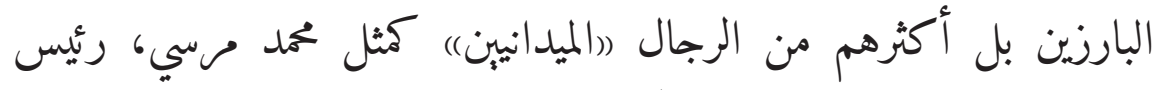

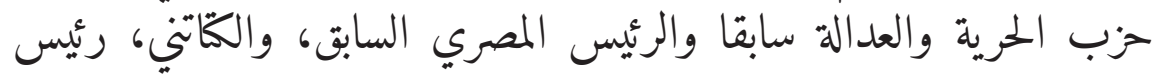

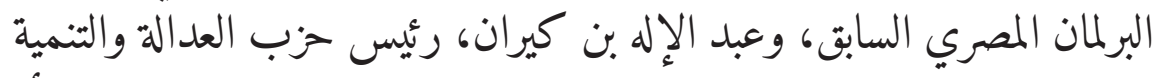

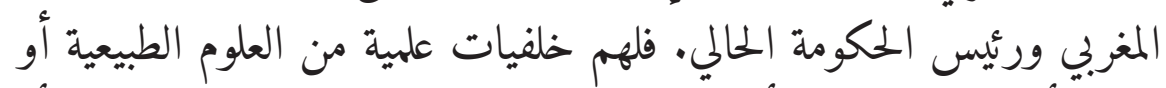

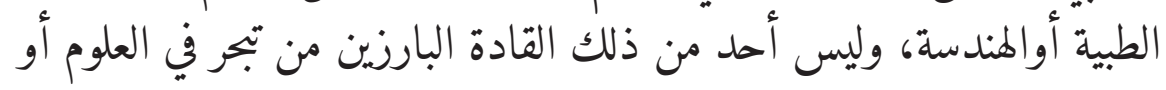

${ }^{22}$ Francis Fukuyama, "The End of History", The National Interest, Summer 1989, p. 16. 
الأفكار الإسلامية. وقد خلت الأحزاب من المفكريين الإسلاميين الباهرين

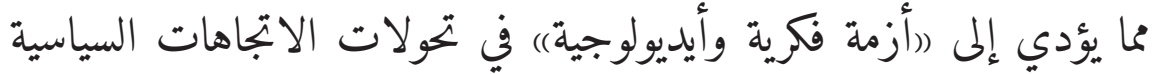

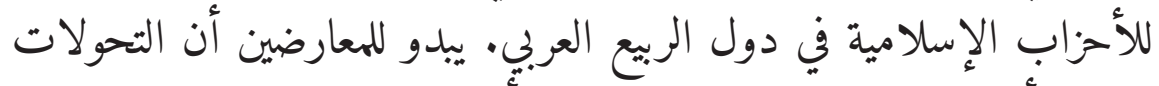

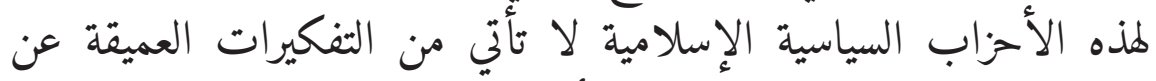

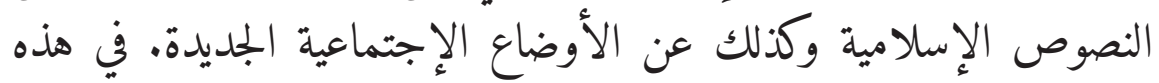

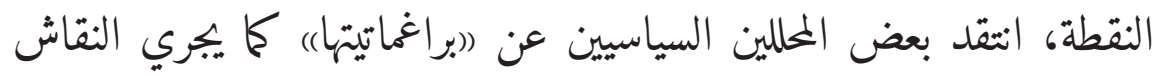

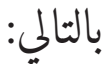

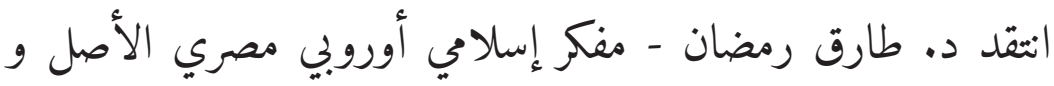

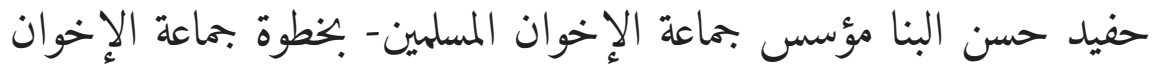

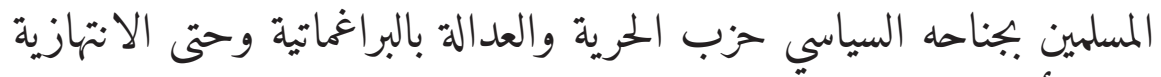

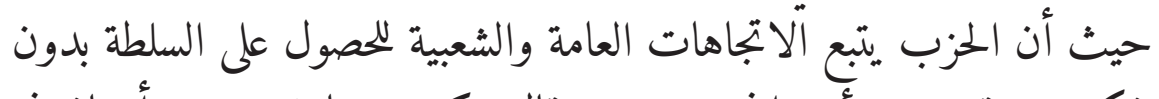

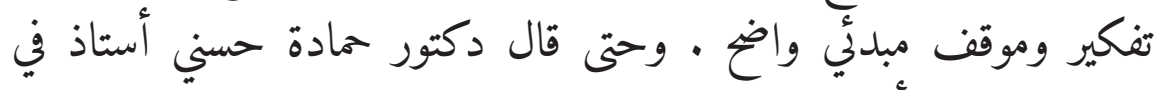

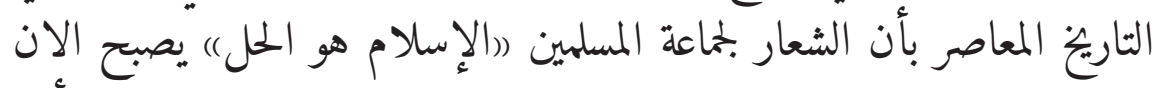

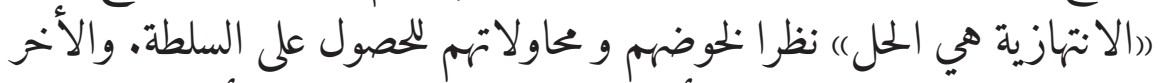

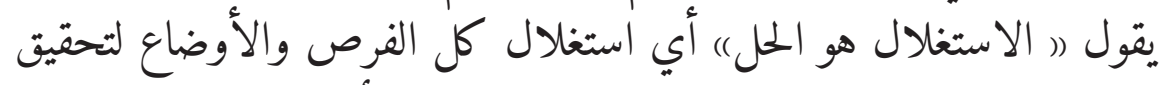

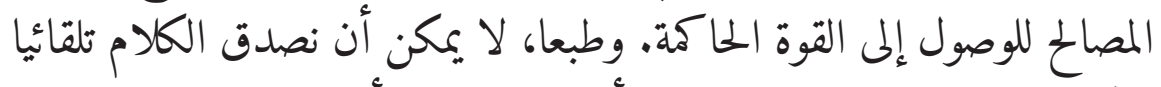

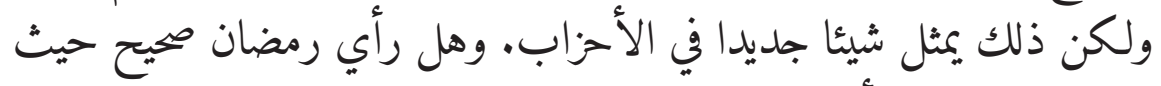

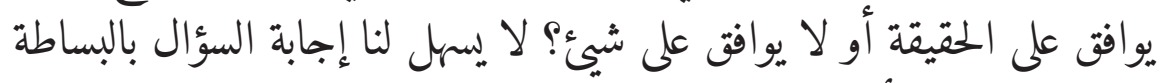

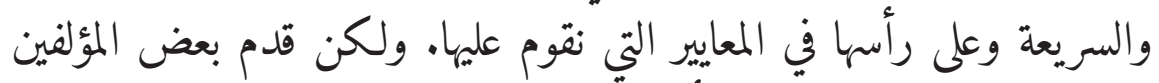

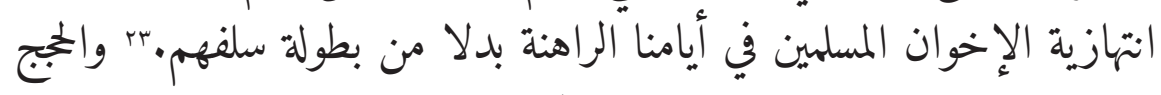

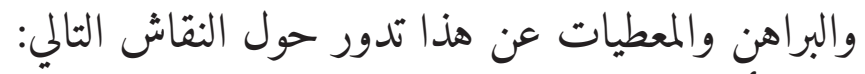

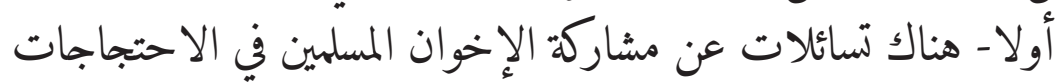

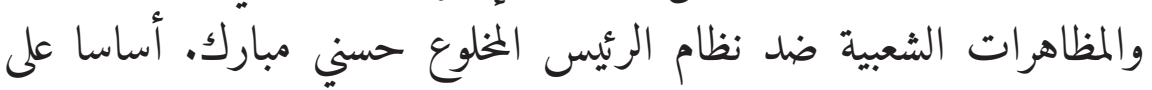

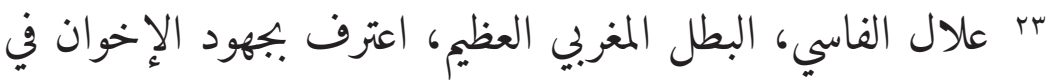

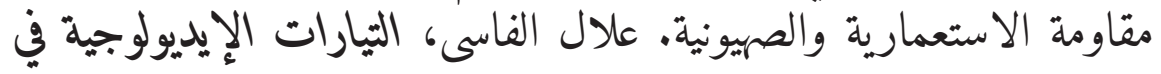

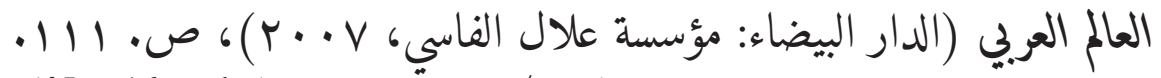
Al-Jāmi áa, Vol. 52, No. 2, 2014 M/1435 H 
Ibnu Burdah

الشعارات والهتافات الميدانية، يمكن القول أن الجماعة كأنها غائبة في ميدان

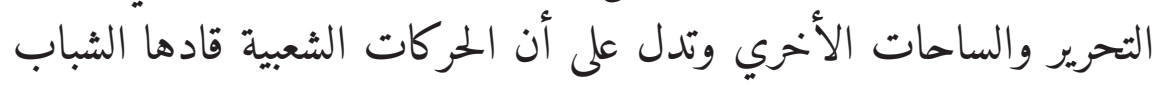

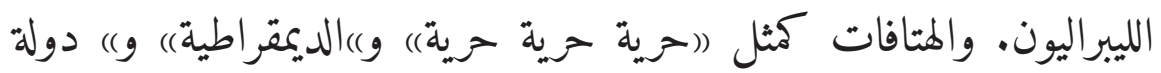

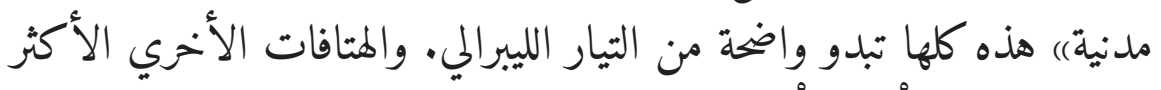

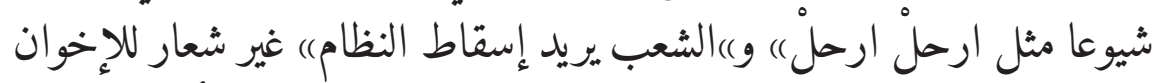

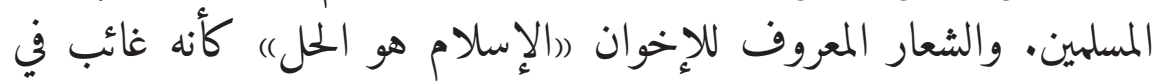
الثورة من بدايتها إلى نهايتها. والموقف الرسمي الذي تمسك به بهاعة بماعة الإخوان المسلمين يتمثل في البيان

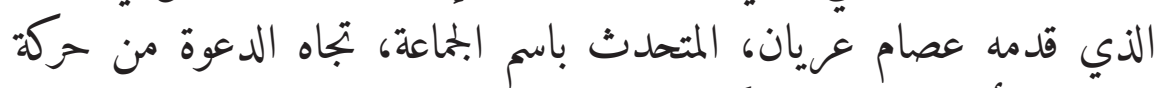

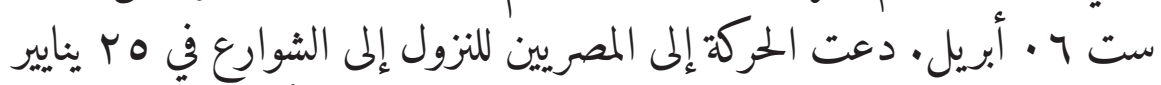

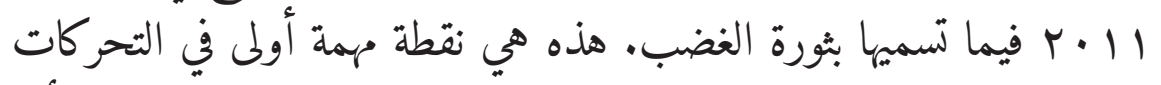

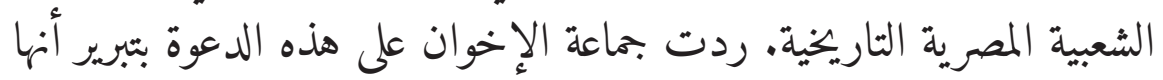

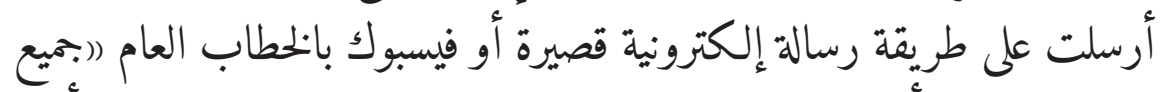

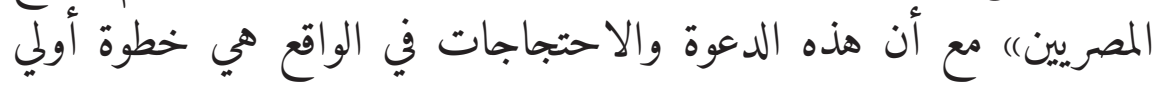

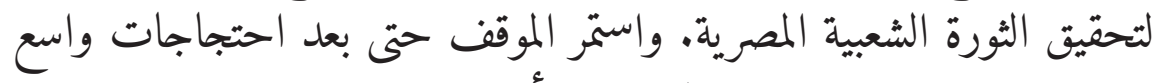

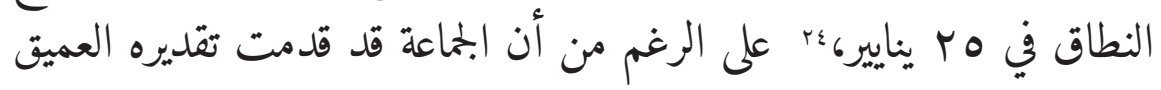

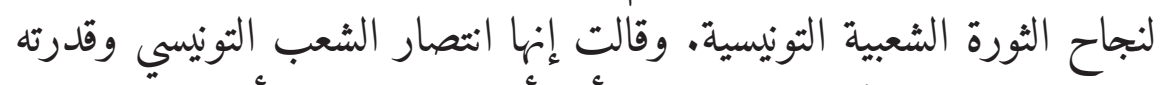

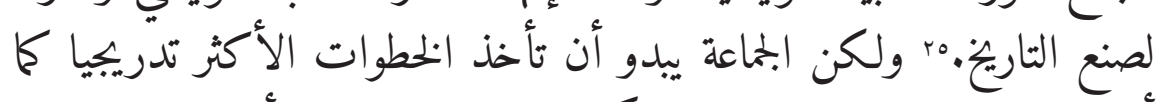

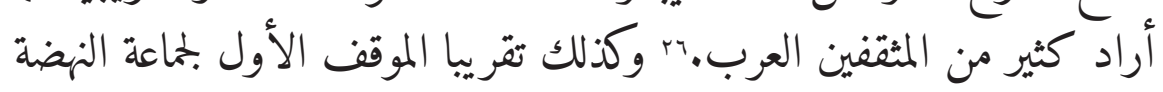

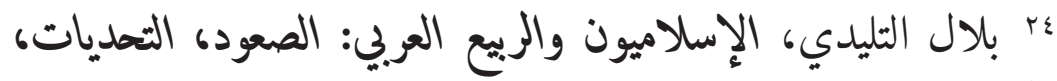

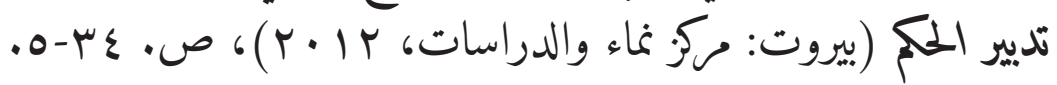

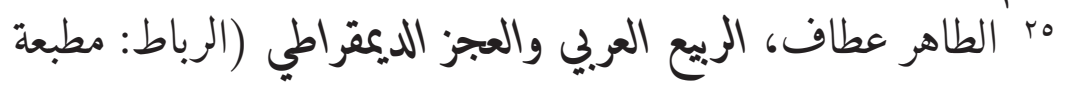

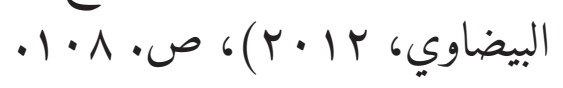

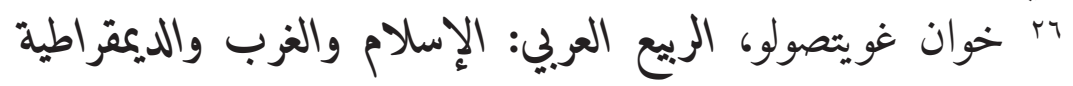

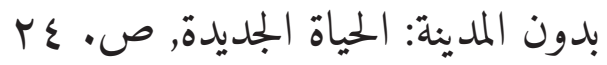




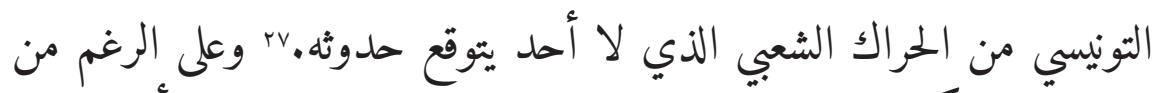

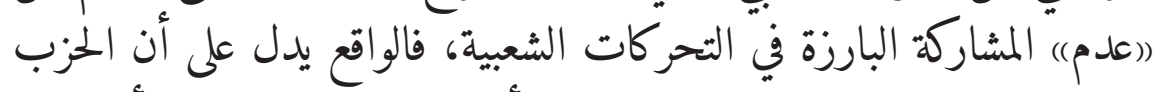

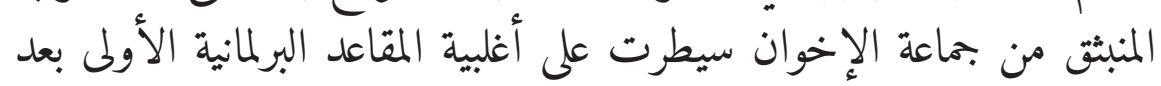

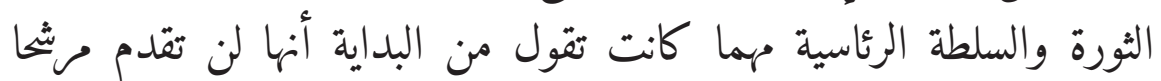

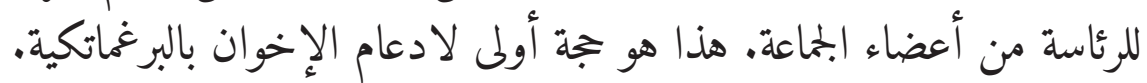

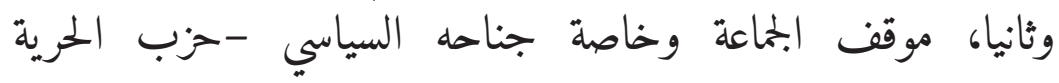

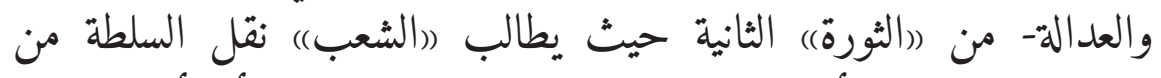

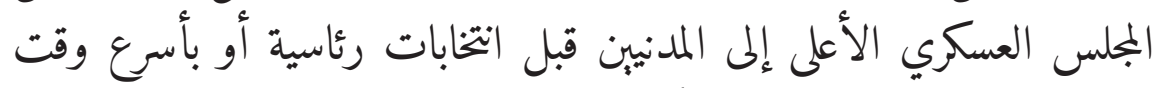

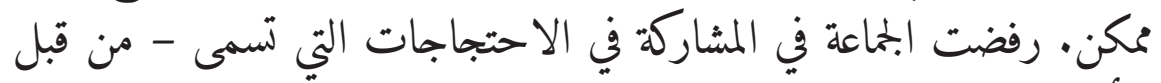

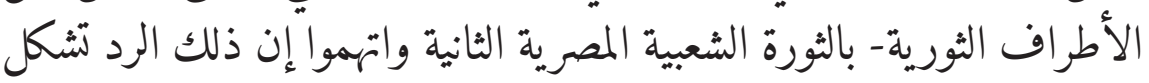

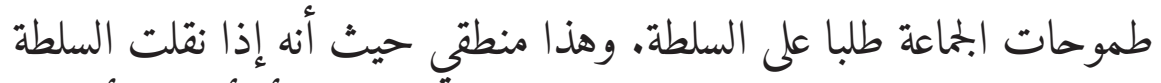

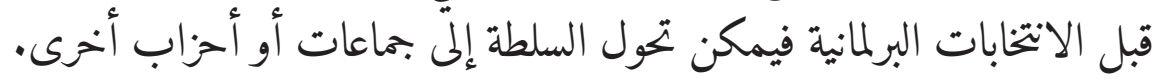

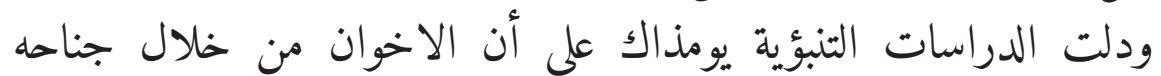

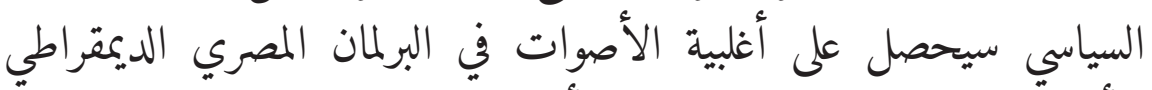

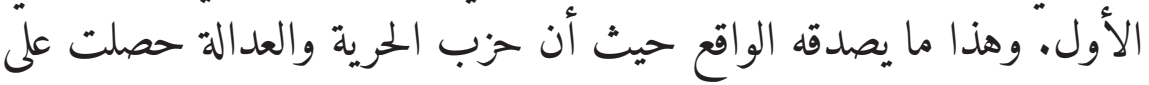

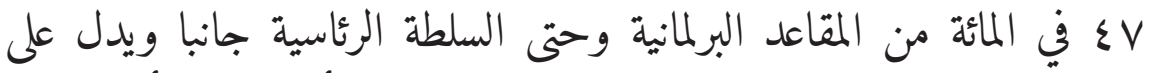

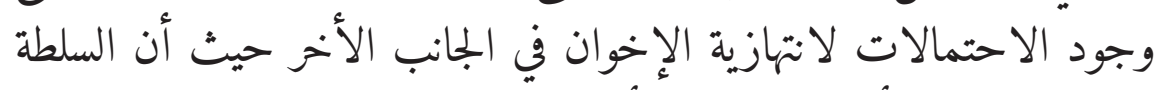

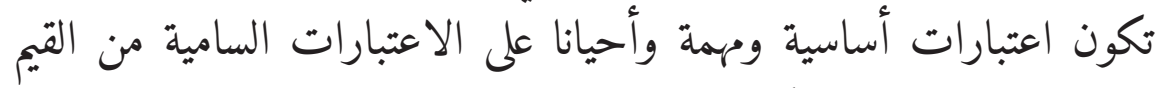

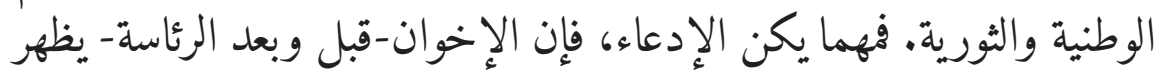

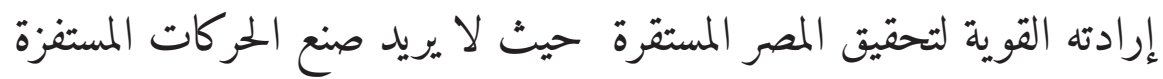

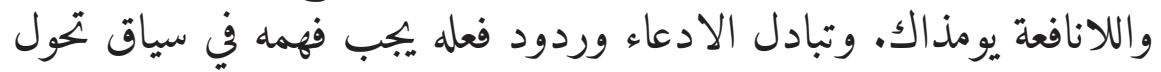

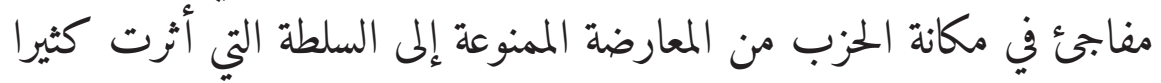

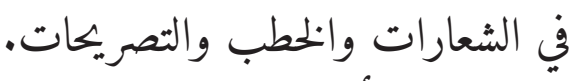

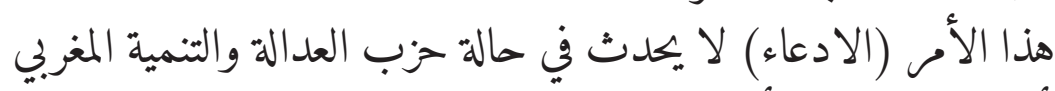

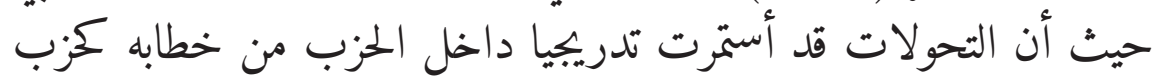

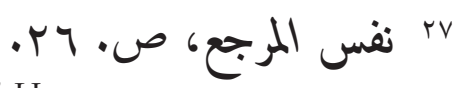




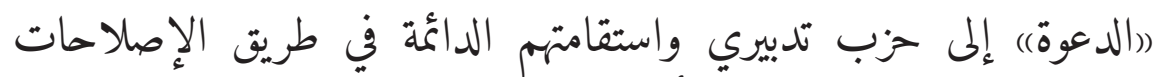

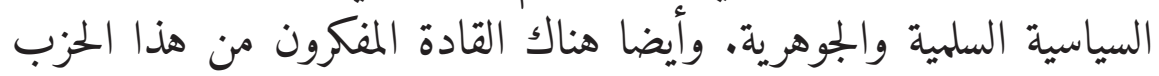

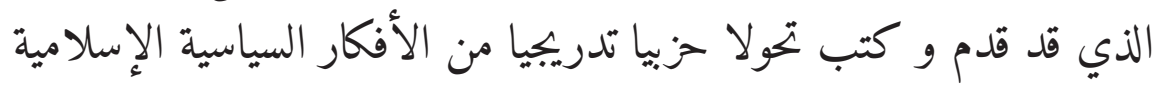

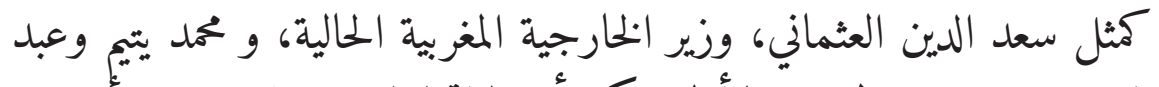

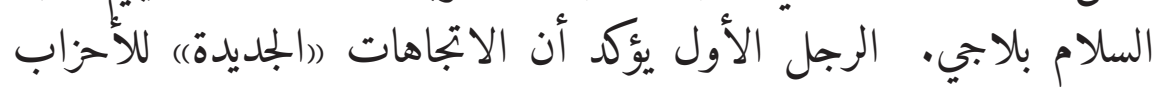

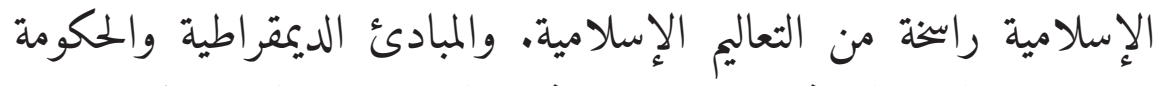

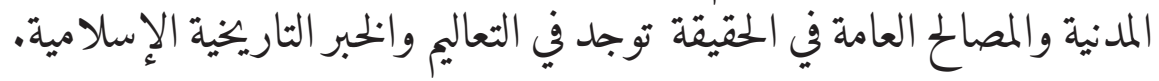

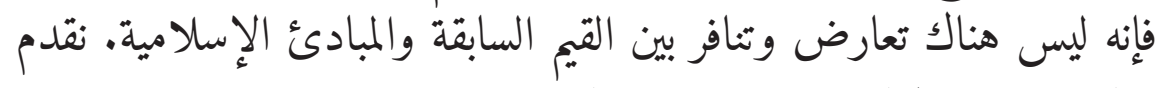
هنا بعض المقتطفات من بعض مؤلفاتهاتها

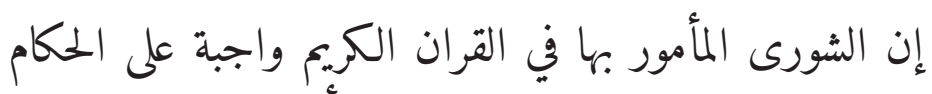

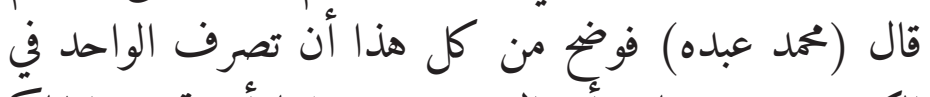

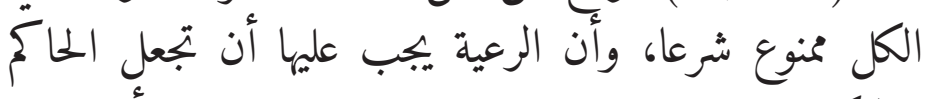

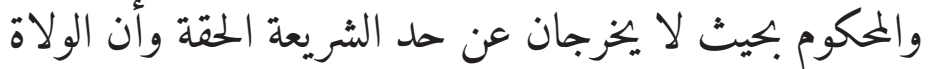

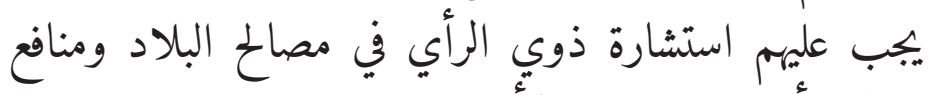

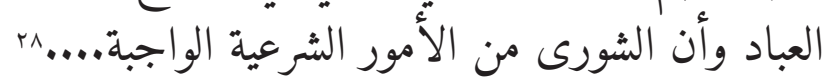

من القضايا التي تحتاج إلى مزيد مناقشة ودراسة لدى المهتمين

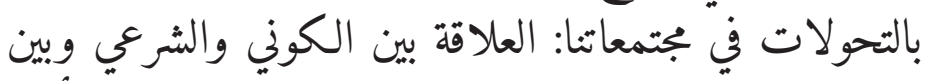

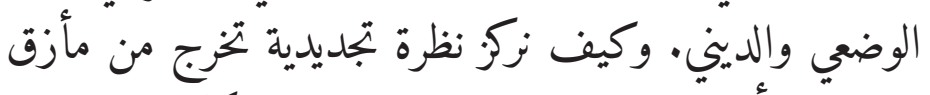

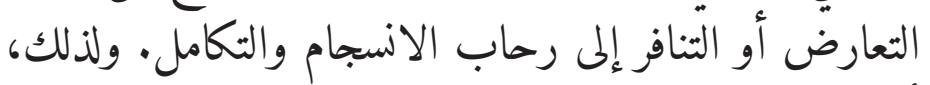

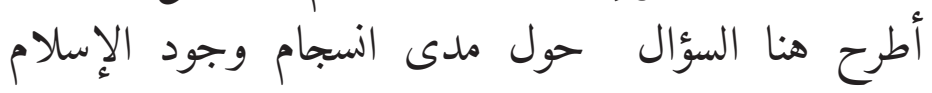

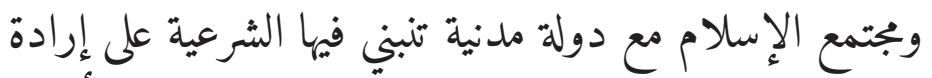

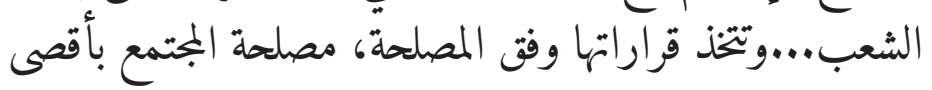

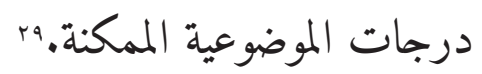

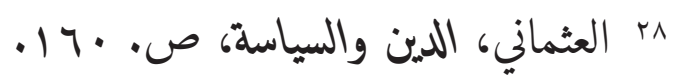

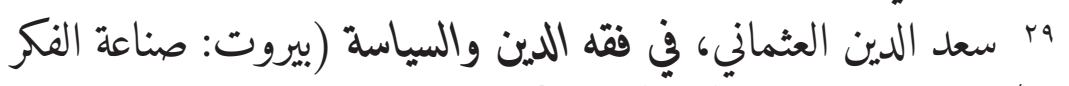
480 Al-Jämiah, Vol. 52, No. 2, 2014 M/1435 H 
في سياق الإصلاحات السياسية المغربية، قال أحد القادة في حزب المباد المباد

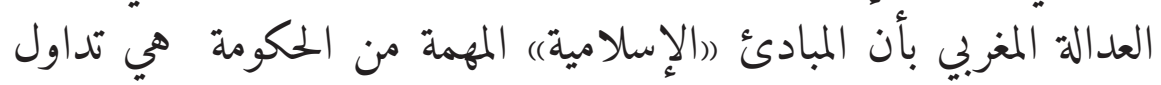
السلطة وضمان التنافس السياسي الشريف و المصالح العامة:

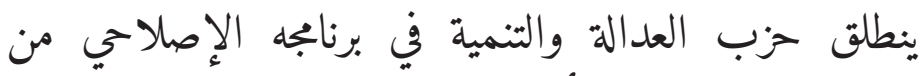

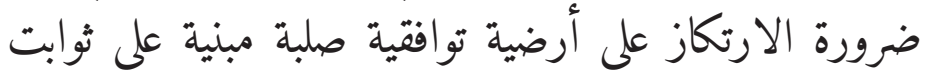
وطنية تكون ضمانا للإستقرار وحفظ المصالح المان العليا للبلاد.

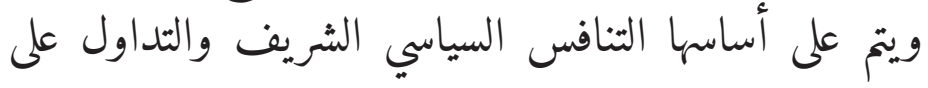

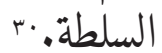

د. سعد الدين العثماني، الأمين العام لحزب العدالة العة والتنمية المغربي

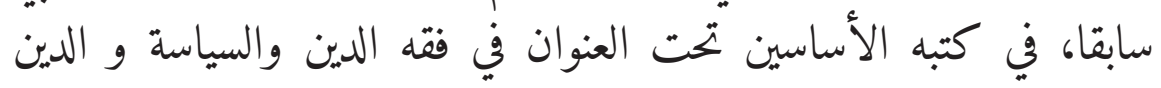

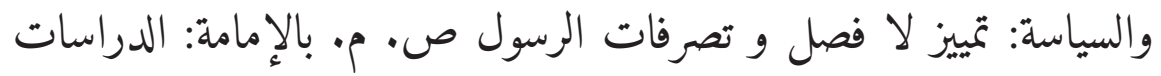

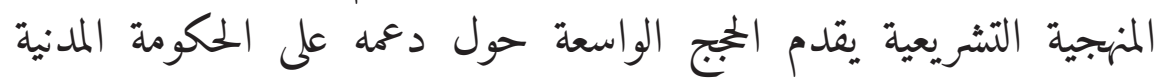

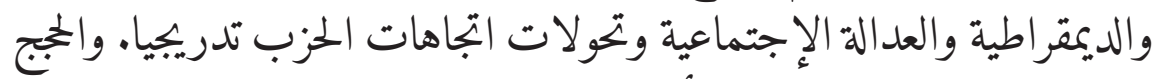

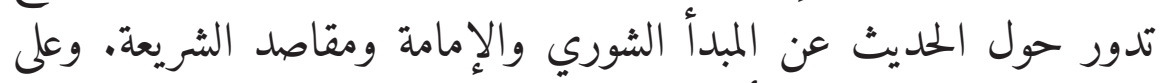

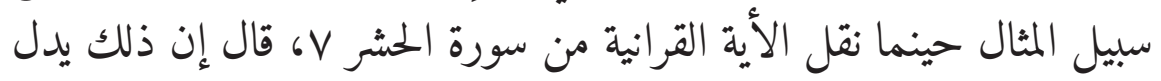

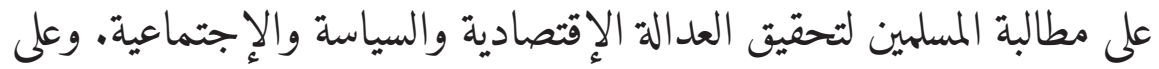

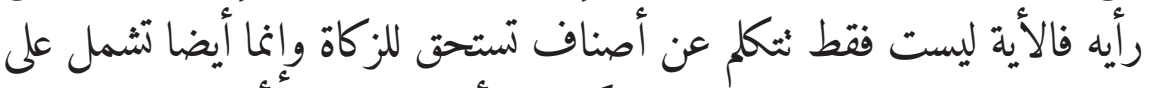

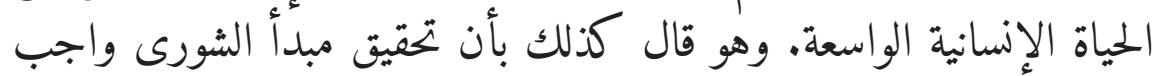

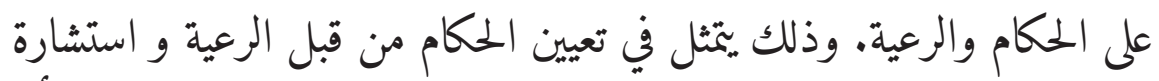

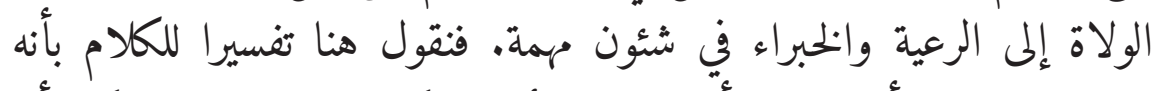

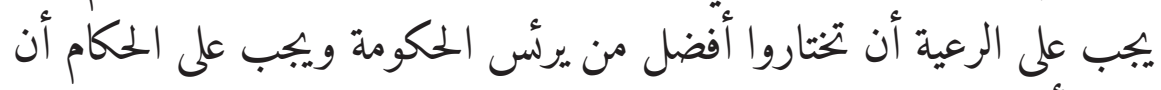

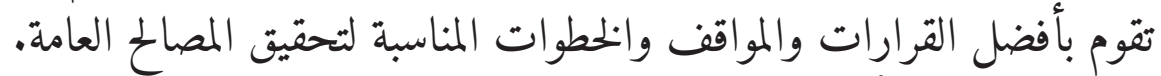
والمبدئ الشورى أيضا يطالب تدوال السلطات والمسئولية المشتركة.

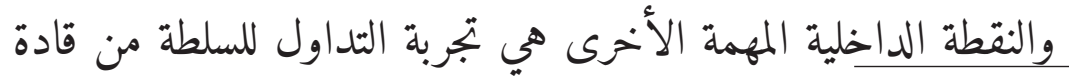

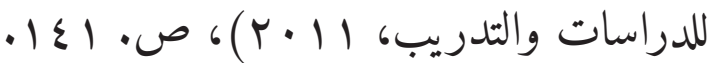

$$
\begin{aligned}
& \text {.r نفس المرجع، ص. } 179 .
\end{aligned}
$$


الأحزاب الإسلامية. على الرغم من تسائلات من موقفهم من الديمقراطية،

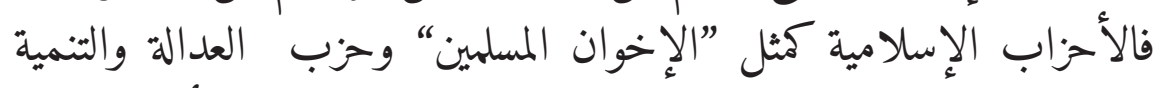

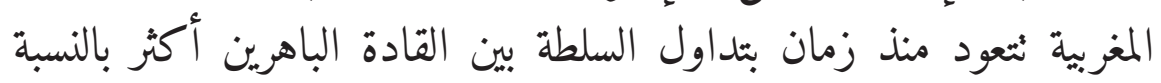

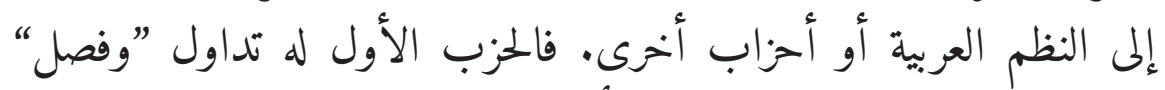

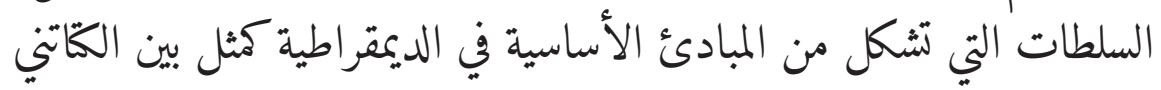

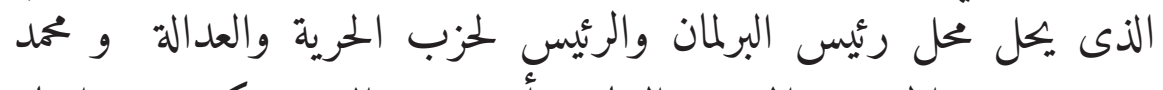

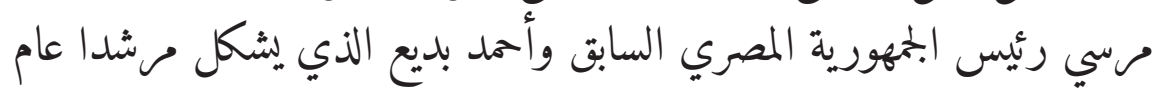

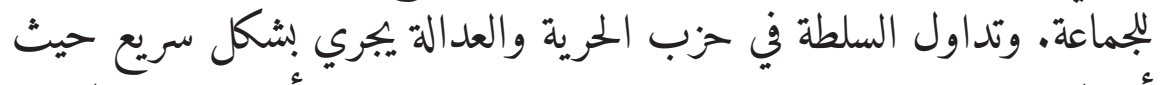

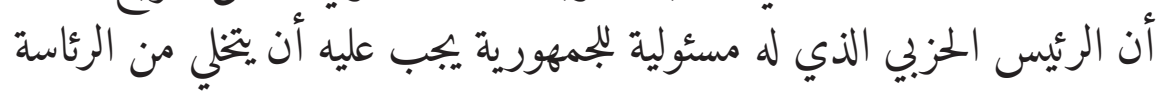

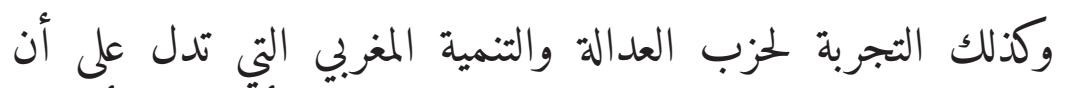

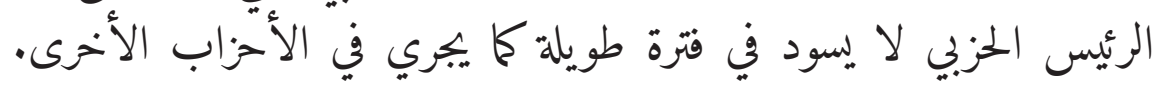

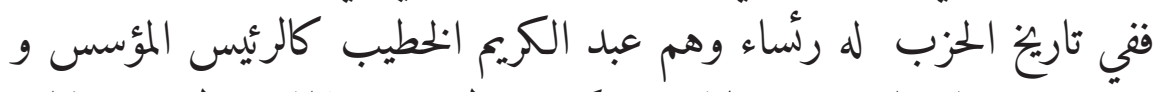

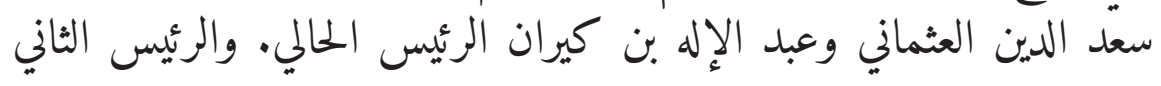

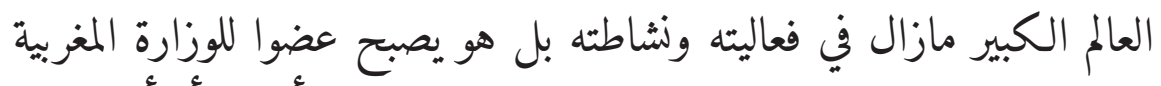

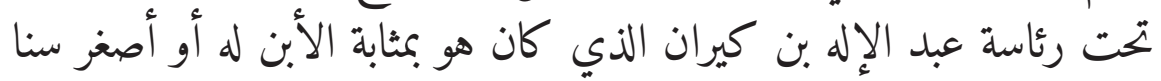

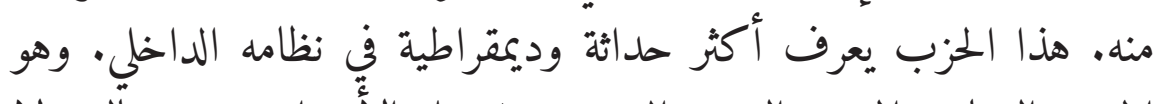

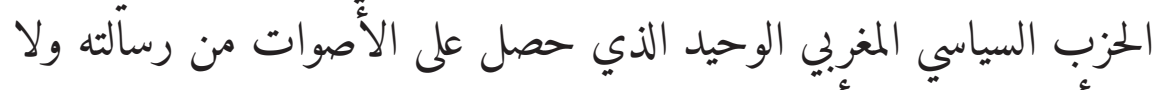

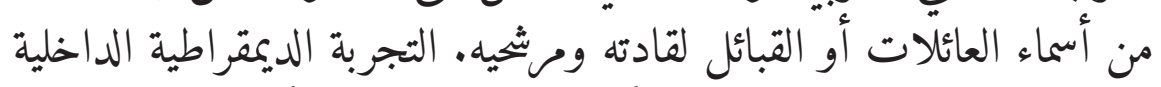

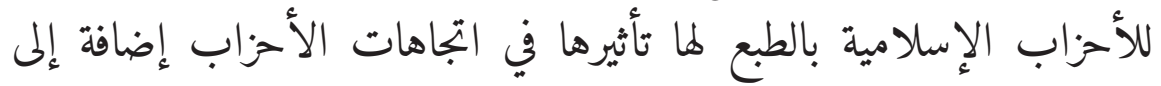
العوامل الخاريجية المذكورة.

\section{ج. الخلاصة}

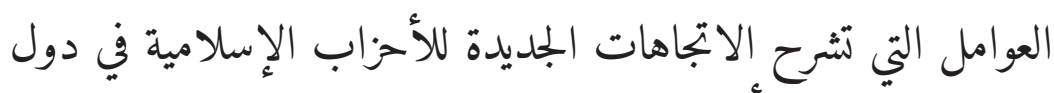

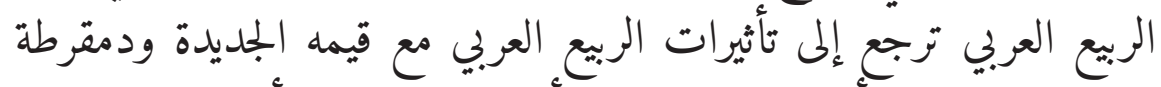

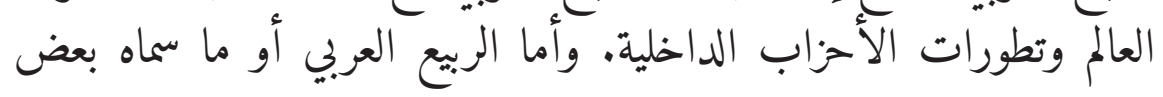




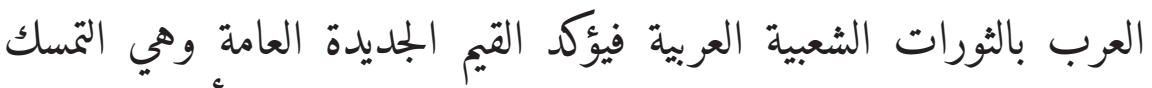

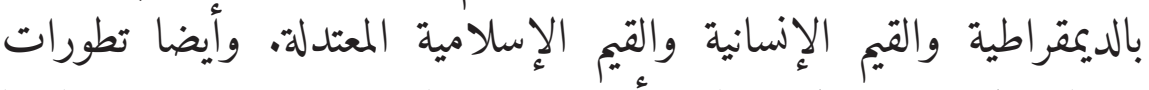

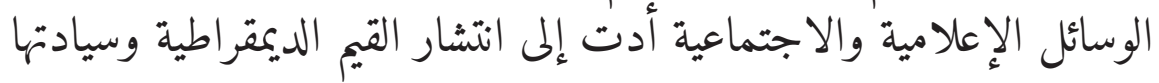

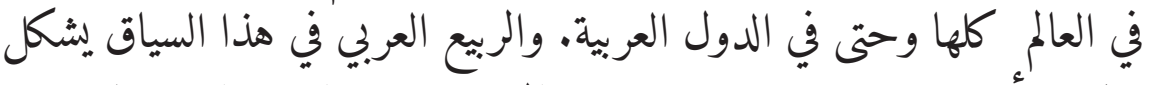

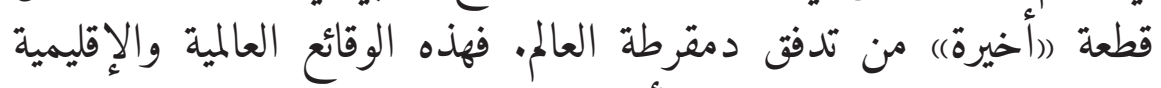

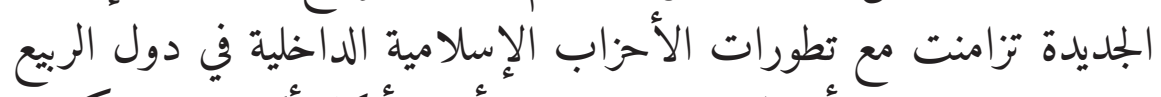

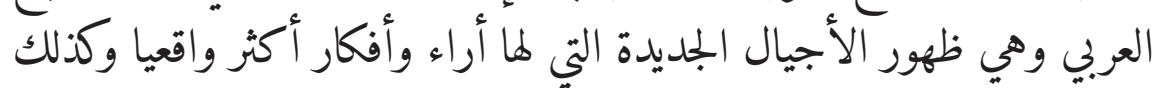

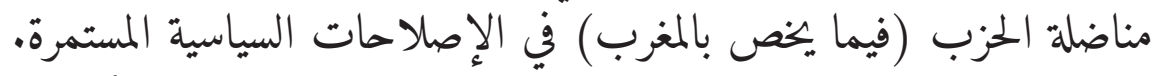

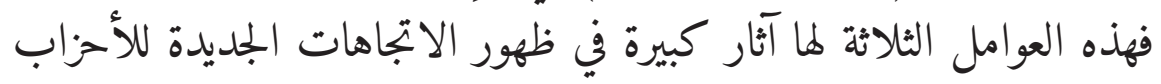
الإسلامية في دول الربيع العربي.

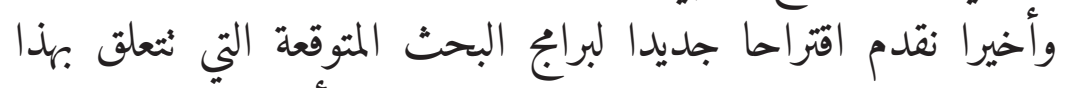

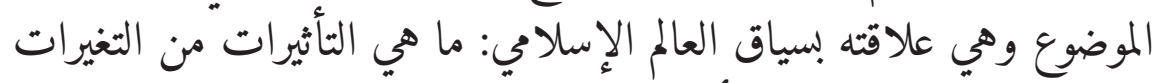

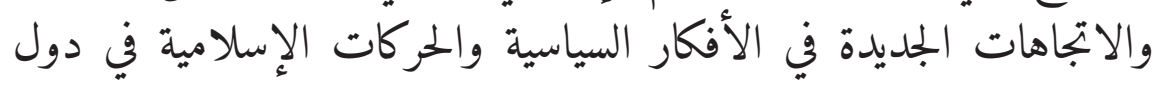

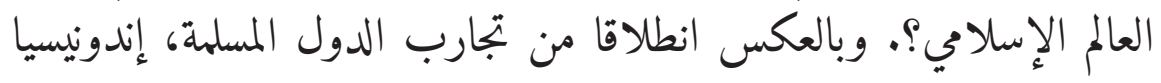

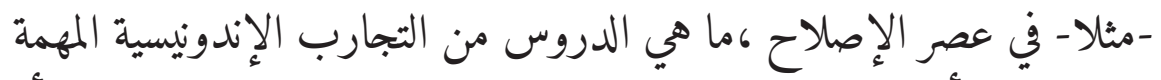

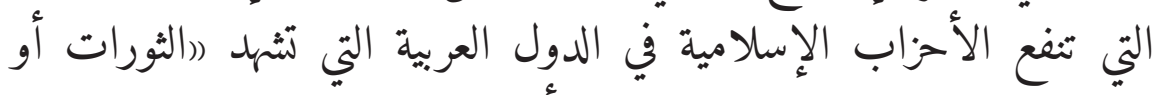

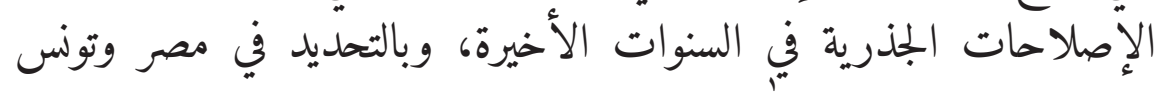

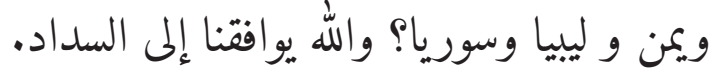


Ibnu Burdah

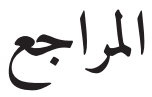

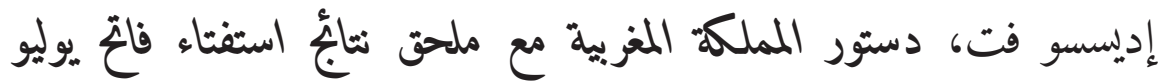

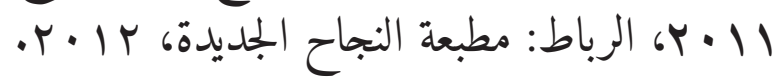

بلال التليدي، الإسلاميون والربيع العربي: الصعود، التحديات، تدبير الحكم،

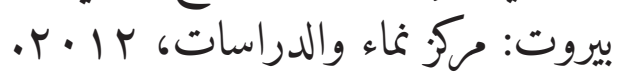

حبيب، رفيق، الدولتان: الإسلاميون والدولة القومية، قاهرة: دار الشروق

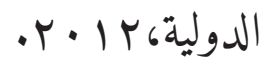

حزب العدالة والتنمية، كراسة الموتمر الوطني السابع لحزب العدالة والتنمية

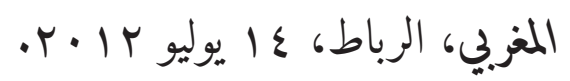

حزب الحرية والعدالة، نص برناج حزب الحرية والعدالة، قاهرة: حزب الحب

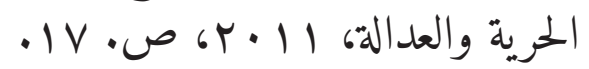

خوان غويتصولو، الربيع العربي: الإسلام والغرب والديمقراطية، الحياة

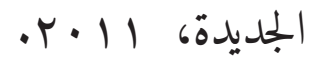

الطاهر عطاف، الربيع العربي والعجز الديمقراطي، الرباط: مطبعة البيضاوي، .$r \cdot 1 r$

العثماني ،سعد الدين، في فقه الدين والسياسة، بيروت: صناعة الفكر للدراسات

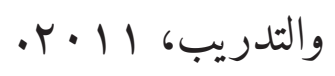

----، الدين والسياسة: تمييز لا فصل، بيروت: المركز الثقافي العربي، و ه . ب. ----م تصرفات الرسول ص. م. مالإمامة: الدراسات المنهجية التشريعية،

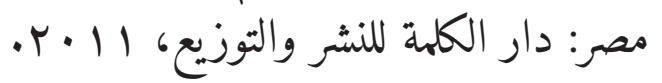

غرنغيوم، جلبير، اللغة والسلطة والمجتمع في المغرب العربي، المغرب: أفريقيا 484

Al-Jämi'ah, Vol. 52, No. 2, 2014 M/1435 H 


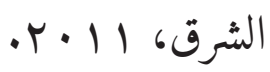

\section{الفاسي، علال، التيارات الإيديولوجية في العالم العربي، الدار البيضاء:

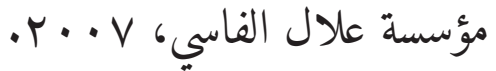

بمحوعة مؤلفين، الانفجار العربي الكبير في الأبعاد الثقافية والاجتماعية،

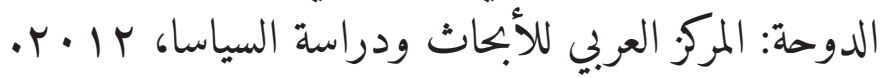

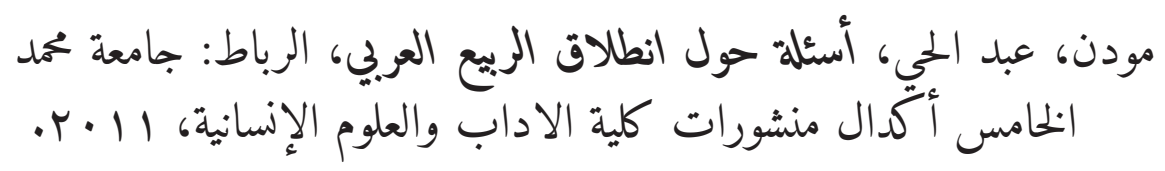

Burdah, Ibnu, Konflik Timur Tengah: Aktor. Isu. dan Dimensi Konflik, Yogyakarta: Tiara Wacana, 2008.

----, Islam Kontemporer: Revolusi dan Demokrasi, Malang: Intrans Publishing, 2014.

Fukuyama, Francis, "The End of History”, The National Interest, Summer 1989.

Hagopian, M. N., Regimes, Movements, and Ideologies: A Comparative Introduction to Political Science, New York: Longman, 1978.

Maogoto, J.N. and A. Coleman, “The Arab Spring's Constitutional Indegestion: Has Democracy failed in the Middle East?", Liverpool Law Review, vol. 35, no. 2, 2014, pp. 105-34 [http://dx.doi. org/10.1007/s10991-014-9150-7].

Waghid, Y. and N. Davids, "On the (Im)possibility of Democratic Citizenship Education in the Arab and Muslim World", Studies in Philosophy and Education, vol. 33, no. 3, 2014 [http://dx.doi. org/10.1007/s11217-013-9393-0]. 